\title{
Hydrogeologic Data for the Coconino Plateau and Adjacent Areas, Coconino and Yavapai Counties, Arizona
}

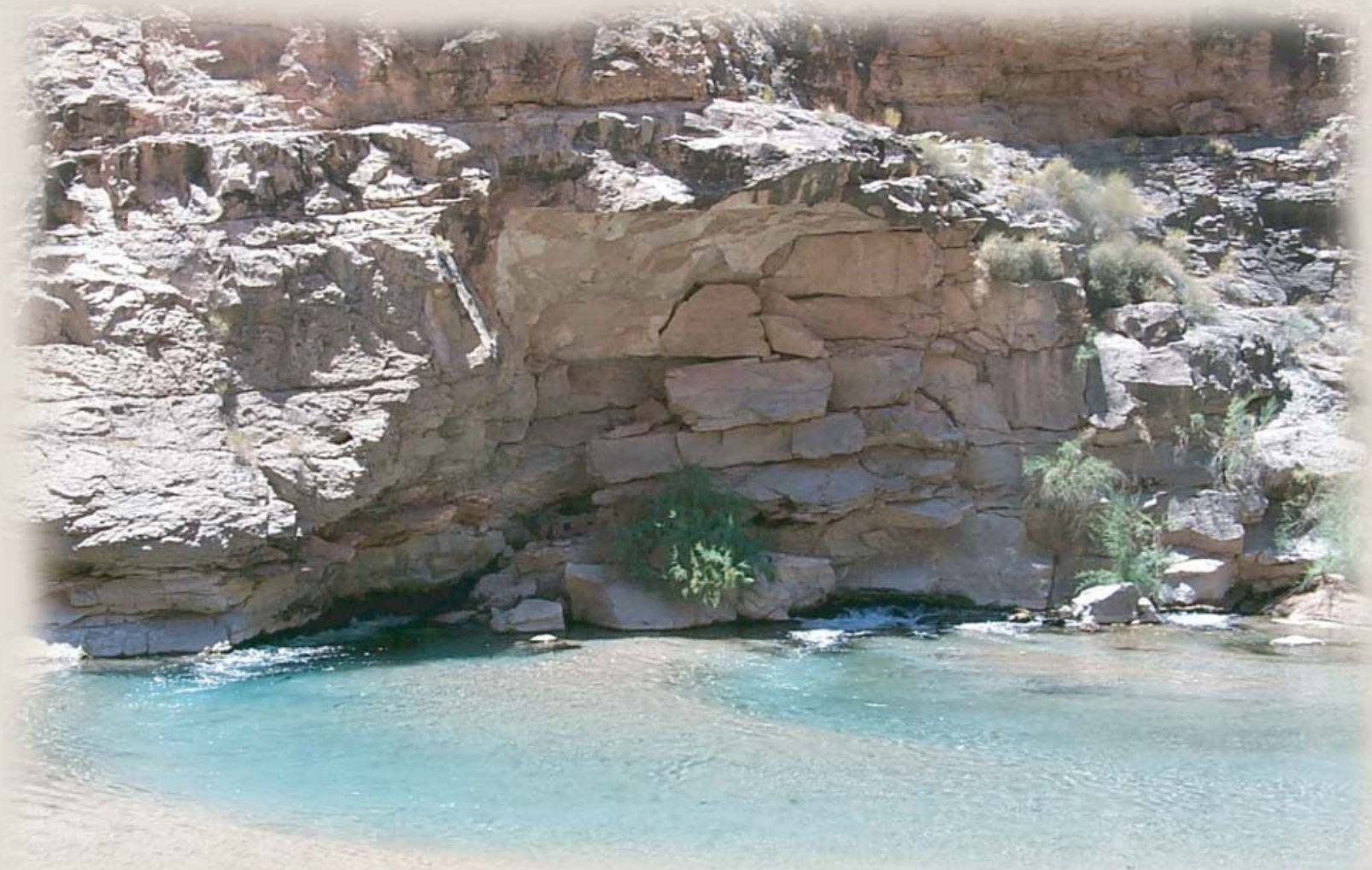

Open-File Report 02-265 


\section{Hydrogeologic Data for the Coconino Plateau and Adjacent Areas, Coconino and Yavapai Counties, Arizona}

Open-File Report 02-265

Prepared in cooperation with the

CITY OF WILLIAMS 


\section{U.S. DEPARTMENT OF THE INTERIOR \\ GALE A. NORTON, Secretary}

U.S. GEOLOGICAL SURVEY

Charles G. Groat, Director

The use of firm, trade, and brand names in this report is for identification purposes only and does not constitute endorsement by the U.S. Geological Survey.

For additional information write to:

District Chief

U.S. Geological Survey

Water Resources Division

520 N. Park Aveune, Suite 221

Tucson, AZ 85719-5035
Copies of this report can be purchased from:

U.S. Geological Survey

Information Services

Box 25286

Federal Center

Denver, C0 80225-0046

Information regarding research and data-collection programs of the U.S. Geological Survey is available on the Internet via the World Wide Web. You may connect to the home page for the Arizona District Office using the URL http://az.water.usgs.gov. 


\section{CONTENTS}

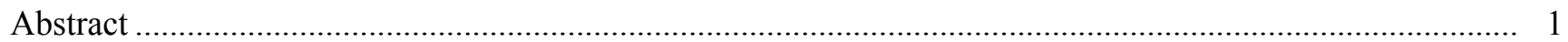

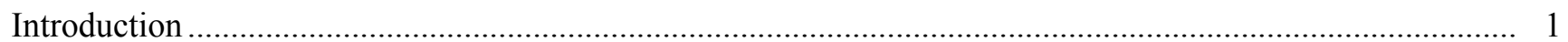

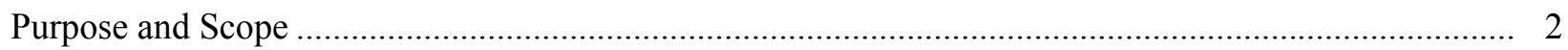

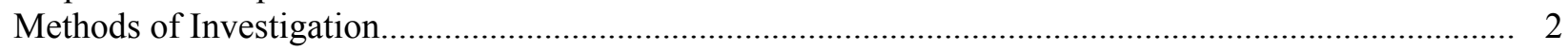

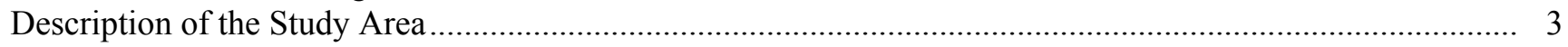

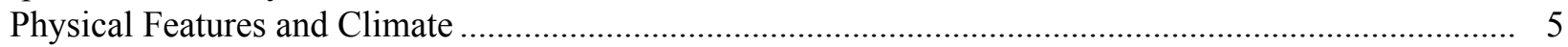

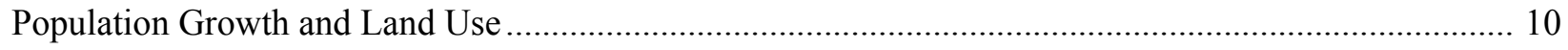

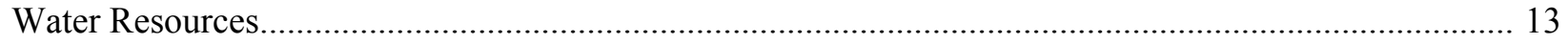

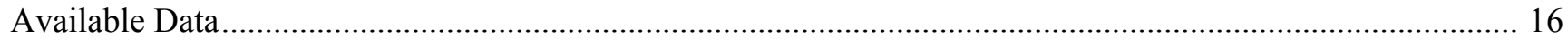

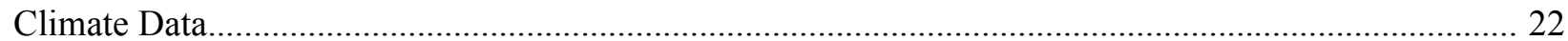

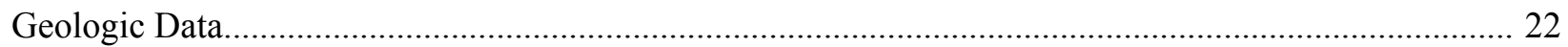

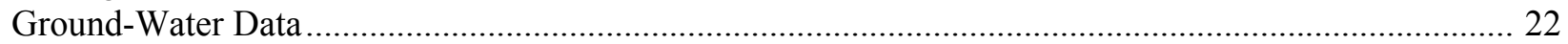

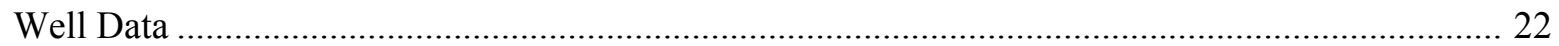

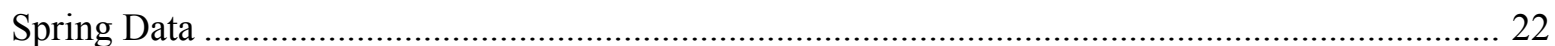

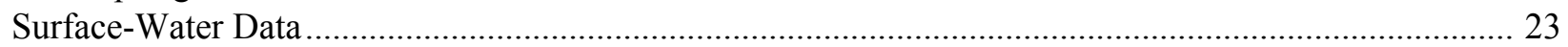

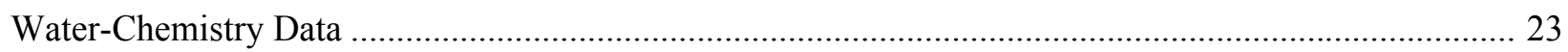

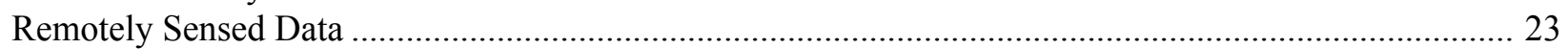

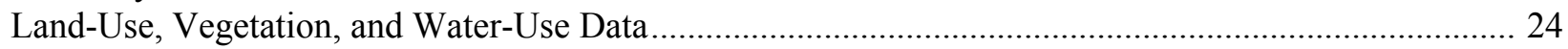

Data Requirements for Comprehensive Investigative Studies ................................................................... 24

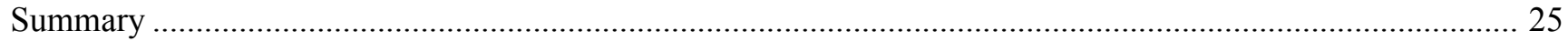

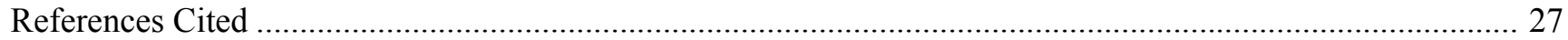




\section{FIGURES}

1. Map showing Location of the study area, current and discontinued precipitation and streamflow-gaging stations, and geographic features, Coconino Plateau, Arizona ..................... 4

2. Map showing Surface geology and geologic structure of the Coconino Plateau, Arizona .................. 6

3. Sketch showing Generalized stratigraphic section and cross section of the

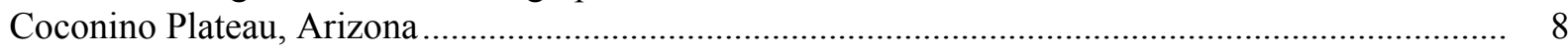

4. Graphs showing Average annual precipitation at selected precipitation stations on the Coconino Plateau, Arizona.

5. Map showing Mean annual precipitation on the Coconino Plateau, Arizona .................................. 12

6. Graphs showing Locations of wells and springs, and hydrographs showing depth to water in selected wells, Coconino Plateau, Arizona....

7. Graphs showing Discharge at selected streamflow-gaging stations on the Coconino Plateau, Arizona....

8. Shaded relief digital elevation model for the Coconino Plateau study area, Arizona

9. Remotely sensed infrared image of the Coconino Plateau study area, Arizona, using Thematic Mapper bands 1, 4, and 7, June 1993

10. Remotely sensed visible color image of the Coconino Plateau study area, Arizona, using Thematic Mapper bands 1, 2, and 3, June 1993

11. Map showing Isostatic residual gravity and aeromagnetic anomaly data for the Coconino Plateau study area, Arizona 
TABLES available on-line at: http://pubs.usgs.gov/of/2002/0265/ofr02-265_Tables1-7.xls

1. Summary of data sources and data types for the Coconino Plateau, Arizona

2. Well and spring information for the Coconino Plateau, Arizona

3. Hydrologic data for active and discontinued streamflow-gaging stations on the Coconino Plateau, Arizona

4. Water-chemistry data for selected wells, springs, and surface-water sites on the Coconino Plateau, Arizona

5. Constituents that exceed U.S. Environmental Protection Agency Maximum Contaminant Levels and Secondary Maximum Comtaminant Levels for drinking water at selected wells, springs, and surface-water sites on the Coconino Plateau, Arizona

6. Climate data from active and discontinued weather stations on the Coconino Plateau, Arizona

7. Estimated ground-water and surface-water withdrawals on the Coconino Plateau, Arizona, 1990-2000

Format: American International Standard Code for Information Interchange (ASCII), Microsoft Excel 2000, and Adobe Acrobat PDF (for final version of this report)

Operating system used: Windows 2000 
WELL (A-14-05)19cda
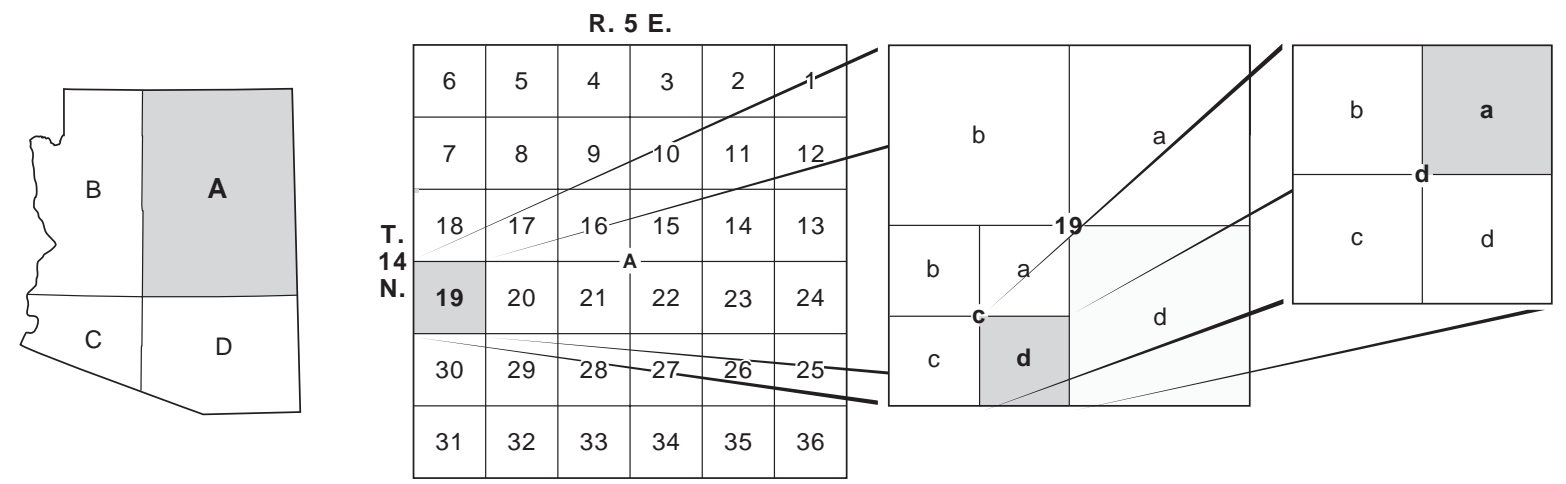

Quadrant A, Township 14 North, Range 5 East, section 19, quarter section c, quarter section d, quarter section a

The well numbers used by the U.S. Geological Survey in Arizona are in accordance with the Bureau of Land Management's system of land subdivision. The land survey in Arizona is based on the Gila and Salt River meridian and base line, which divide the State into four quadrants and are designated by capital letters A, B, C, and D in a counterclockwise direction beginning in the northeast quarter. The first digit of a well number indicates the township, the second the range, and the third the section in which the well is situated. The lowercase letters $\mathrm{a}, \mathrm{b}, \mathrm{c}$, and $\mathrm{d}$ after the section number indicate the well location within the section. The first letter denotes a particular 160 -acre tract, the second the 40 -acre tract and the third the 10 -acre tract. These letters also are assigned in a counterclockwise direction beginning in the northeast quarter. If the location is known within the 10 -acre tract, three lowercase letters are shown in the well number. Where more than one well is within a 10 -acre tract, consecutive numbers beginning with 1 are added as suffixes. In the example shown, well number (A-14-05)19cda designates the well as being in the SW1/4, SE1/4, NE1/4, section 19, Township 14 North, and Range 5 East.

WELL-NUMBERING SYSTEM, NAVAJO RESERVATION, ARIZONA
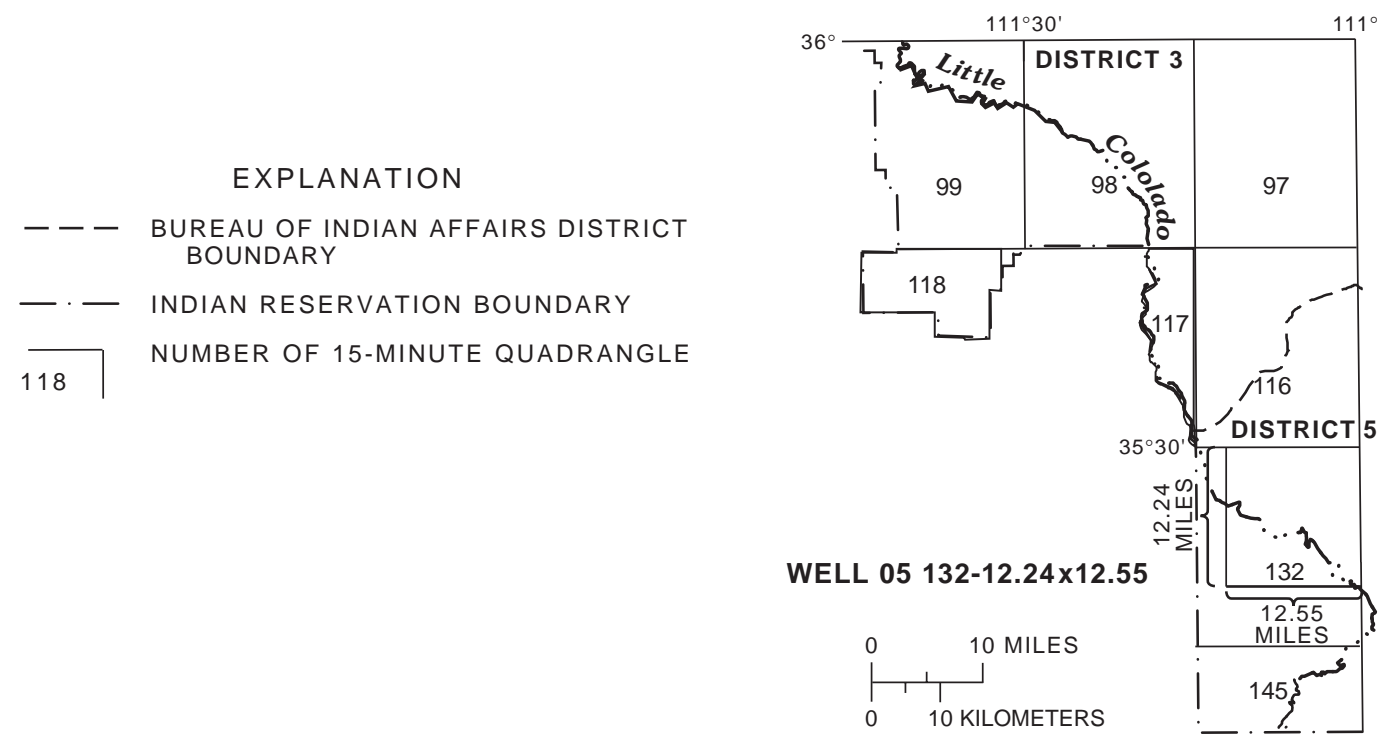

In the Navajo Reservation, where public land surveys have not been made, the local identifier is a filed number that consists of three parts. The first part is formed from the Bureau of Indian Affairs (BIA) district number. The second part is the 15-minute quadrangle number also assigned by the BIA. The third part is the quadrangle location number and indicates the position of a site within a 15-minute quadrangle and consists of two parts. The first part is the distance in miles west of the northeast corner of the quadrangle, and the second part is the distance in miles south of the northeast corner of the quadrangle. 


\title{
Hydrogeologic Data for the Coconino Plateau and Adjacent Areas, Coconino and Yavapai Counties, Arizona
}

\author{
By Donald J. Bills and Marilyn E. Flynn
}

\begin{abstract}
Data on geology, topography, hydrology, climate, land use, and vegetation were compiled between October 2000 and September 2001 and assembled into a database for use by local and regional waterresources managers and for future water-resource investigations. The hydrologic data include information on wells, springs, streamflow, water chemistry, and water use. Limitations of the data and additional data needs also were prepared. The roughly 5,000-square-mile Coconino Plateau contains a complex regional aquifer that has become increasingly important as a source of water supply for domestic, municipal, and in-stream uses owing to population growth and development. The flow characteristics of the regional aquifer are poorly understood because the aquifer is deeply buried, which limits exploratory drilling and testing, and because the geologic structure, which controls the occurrence and movement of ground water, is complex. The study area is about 10,300 square miles and, besides containing the entire Coconino Plateau, includes parts of adjacent areas where ground water from the Coconino Plateau discharges. Selected data are presented in tabular or graphical form. All data are available in electronic form.
\end{abstract}

\section{INTRODUCTION}

The water resources of the Coconino Plateau in northern Arizona are under increasing pressure from development. The population of this arid region continues to grow, and the number of visitors to most of the numerous national and state parks and monuments in the region continues to increase each year. About 4.5 to 4.9 million people have visited Grand Canyon National Park (GCNP) each year since 1995 (Ghioto, 2001). Residents, local and tribal governments, facilities managers, Federal interests, and environmental groups within the region recognize the potential consequences of increased water development attendant to population growth. Public input has identified the sustainability, protection, and maintenance of springs and seeps and associated riparian habitat on the Coconino Plateau as major issues that have broad support. Concerns about the effects of water development on regional springs, surface-water and riparian resources, and the availability and sustainability of regional water supplies have led to the organization of several action groups.

Regional stakeholders agree that an improved understanding of the regional hydrogeologic system is needed to address the concerns of water supply and ground-water sustainability. Such an understanding requires a base of information that adequately describes the system. That base of information 
currently does not exist for the Coconino Plateau. Hydrogeologic data is most abundant in the vicinity of large population centers like Flagstaff and Sedona, but is sparse in less populated areas like Williams, Tusayan, Valle, and Cameron. Basic geologic or hydrologic information is nonexistent for large parts of the Coconino Plateau. In order to develop a conceptual hydrogeologic framework for the Coconino Plateau, a comprehensive effort was needed to compile existing data, collect additional data where available, and identify data gaps. The hydrogeologic data in this report will provide critical information for interested water users on the Coconino Plateau. This study also will provide information on the amount and variability of flow in discharge areas of the regional aquifer that support riparian habitat. The compilation of these data and the formulation of a comprehensive database would allow for effective follow-up studies.

This study was done by the U.S. Geological Survey (USGS) in cooperation with the City of Williams. Partial funding of this investigation was provided to the City of Williams through a grant from the Arizona Water Protection Fund Commission (AWPFC). The views and findings of this report do not necessarily represent those of the AWPFC nor the Arizona Department of Water Resources (ADWR). A USGS study of the Coconino Plateau that is part of the ADWR Rural Watershed Initiatives (RWI) will be one of the main benefactors. Through the RWI study, the database will be expanded and refined, and the information developed will be used to complete conceptual and interpretive models for the water-resource systems on the Coconino Plateau.

The hydrogeologic data contained in this report and additional data from this study are available in electronic form and may be obtained from the U.S. Geological Survey office in Tucson, Arizona, or by accessing the Arizona District Web page at URL: http://az.water.usgs.gov/index.html.

\section{Purpose and Scope}

This report presents basic hydrogeologic data that could be used to describe the hydrogeologic framework and ground-water flow systems of the Coconino Plateau. Existing hydrogeologic data were compiled from October 2000 to September 2001. Data are provided on climate, geology, topography, hydrology, land use, vegetation, and water use. The hydrologic data include information on wells, springs, streamflow, water chemistry, and water use. Limitations of the data and types of additional data that would be helpful for follow-up studies also are discussed. Selected data are presented in tabular or graphical form. All data are available in spreadsheet form on the compact disc provided at the back of the report.

\section{Methods of Investigation}

Existing data were identified, inventoried, and compiled. Areal data included climate, geology, topography, hydrology, land use, vegetation, water use, aerial photography, and remotely sensed imagery.

Remotely sensed data such as digital elevation data, satellite and aerial photography, and gravity and aeromagnetic surveys can be useful tools for evaluating the physiography of an area as it relates to the occurrence and distribution of water resources, land use, and vegetation types and patterns. The 7.5-minute digital elevation model (DEM) provides the same coverage as a standard USGS 7.5-minute quadrangle with comparable resolution. DEMs are useful for evaluating the natural features of the landscape and possible geologic structures that can influence the occurrence of water resources.

Point data include the locations of wells and springs, well construction and spring development data, well logs, aquifer properties, water usage, water chemistry, water temperature, water levels, air temperature, precipitation, and stratigraphy. Selected new wells and other holes of opportunity were inventoried where accessible. In addition, 12 unsurveyed springs identified from maps were inventoried to further supplement the database. Streamflow data also were compiled where available. Regional geology, hypsography, aerial photography, and remotely sensed data will facilitate the evaluation of topographic and geologic structural controls on the boundaries of the hydrogeologic flow system. Climate, land-use, vegetation, and water-use data can be used to evaluate recharge and discharge components of the ground-water systems and to establish the boundaries of riparian zones that could be affected by development. Well and spring data provide information necessary for determining the occurrence and movement of ground water.

Data were obtained from Federal, State, tribal, and municipal databases; from university theses; reports and data of private consultants; from private 
landowners; and from USGS field observations (table 1). USGS databases include the National Water Information System (NWIS); the Earth Resources Observations Systems National Elevation Dataset, National Aerial Photograph Program, and National Land Cover Characterization program; and the National Biological Information Infrastructure Project. Additional spatial data are from the USGS National Geophysical Data grids (Phillips and others, 1993). Other Federal databases were those of the National Weather Service, National Park Service (NPS), and Forest Service. State databases were those of the Arizona Department of Water Resources (GroundWater Site Inventory; GWSI), the Arizona Geological Survey (AGS), and the Arizona State Land Department (ASLD). Tribal databases were those of the Havasupai Tribe. Municipal databases were those of the cities of Flagstaff and Williams and the towns of Valle and Tusayan. University theses were those from Northern Arizona University (NAU) and the University of Nevada at Las Vegas (UNLV). All data acquired for this project are to be incorporated into a regional database that includes data developed for hydrogeologic investigations in adjacent areas to the south (Parker and Flynn, 2000; Betsy Woodhouse, Hydrologist, USGS, written commun., 2001). Spatial components of the data are to be used to build geographic information system data files and coverages that will facilitate the evaluation of data suitability for the development of conceptual hydrogeologic framework information.

Selected wells and selected unsurveyed springs inventoried for this study were located by map and Differential Global Positioning System to obtain precise location and elevation data. All available well$\log$, construction, development, pump or aquifer test, and water-chemistry data were obtained for wells. All available lithologic, development, discharge, physical characteristic, and water-chemistry data were obtained for springs.

Activities of this study were coordinated with activities of other groups when possible to optimize data collection, reduce duplicated efforts, and share data with groups that are compiling information for the North-Central Arizona Regional Water Study. The North-Central Arizona Regional Water Study is a group of Federal, State, municipal, tribal, local, and environmental agencies that are concerned about ground-water development on the Coconino Plateau and the attendant demand for water. This group has organized to facilitate studies on growth, development, water demand, and water supply. Some of the other water studies currently in progress by stakeholders of the North-Central Arizona Regional Water Study include: (1) recent Havasupai tribal spring inventories (Tom Crouch, hydrologist, Natural Resources Consulting Engineers, written commun., 2000), (2) ongoing NPS/AWPFC and NPS/USGS inventory of water resources on the south rim of Grand Canyon (John Rihs, hydrologist, NPS, written commun. 2000), (3) Forest Service inventory of springs (John Ward, hydrologist, Hydro Geo Chem Inc., written commun., 2001), (4) USGS evaluation of water resources in adjacent basins as part of the RWI (John Parker and Betsy Woodhouse, hydrologists, USGS, oral commun., 2000), and (5) current academic research on water resources of the Coconino Plateau and south rim of Grand Canyon (A.E. Springer, Ph.D., professor, Northern Arizona University, oral commun., 2000, and Dave Kreamer, professor, University of Nevada Las Vegas, written commun., 2000).

All well and spring data from the data inventory and compilation were reviewed for completeness and consistency and were examined for accuracy, precision, redundancy, and errors. Well and spring information with errors or questionable data were flagged for field verification at a later date as part of the RWI study. In addition, newly drilled wells, other holes of opportunity, and accessible unsurveyed springs were field inventoried and evaluated. As the data were refined they were loaded into the USGS NWIS database where they will be accessible through USGS Web pages. The database developed through this study represents the core of information needed by the RWI study of the water resources of the Coconino Plateau. As part of the RWI study, questionable data and additional data needs identified by this study are to be resolved, and all data are to be evaluated to develop conceptual, water budget, and framework models of the Coconino Plateau. These data are to be used in the construction of interpretive and predictive groundwater flow models that may be used to address issues about the sustainability of water resources in the area.

\section{DESCRIPTION OF THE STUDY AREA}

The Coconino Plateau is a subprovince of the Colorado Plateau in north-central Arizona, south of the Colorado River (fig.1; Billingsley and Hendricks, 


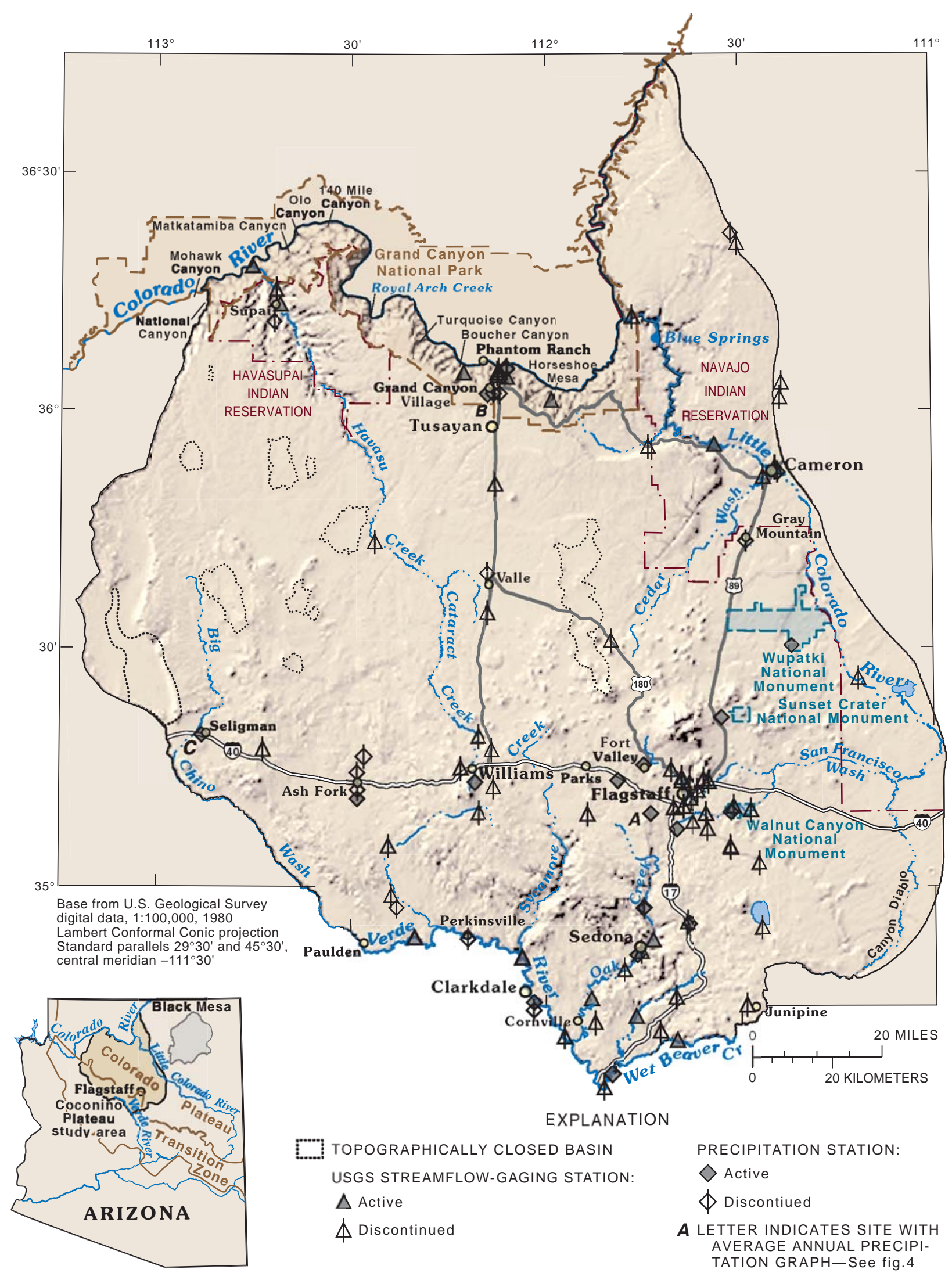

Figure 1. Location of the study area, current and discontinued precipitation and streamflow-gaging stations, and geographic features, Coconino Plateau, Arizona. 
1989). The study area encompasses about 10,300 square miles, including all of the Coconino Plateau and parts of the Little Colorado River and Verde River Basins. The boundaries of the study area are defined by the Colorado River to the north, The Aubrey Fault to the west, the Mogollon Escarpment and Verde River to the south, and the Echo Cliffs Monocline and western edge of the Black Mesa Basin to the east (fig. 1). These features define the preliminary hydrogeologic boundaries of the study area and represent physical controls on the occurrence and movement of surface-water and ground-water resources on a regional scale. The main area of focus for this study is the Coconino Plateau.

\section{Physical Features and Climate}

The Coconino Plateau, about 5,000 square miles in area, is a Cenozoic aged, upland, physiographic province composed of a thick sequence of nearly flatlying Paleozoic and younger consolidated sedimentary rocks exposed at the south rim of Grand Canyon (Billingsley and Hendricks, 1989; Beus and Morales, 1990). Erosion of these sediments on the plateau has exposed a land surface characterized by a complex series of low relief hills and mesas with broad mature valleys.

The hydrogeologic framework of the Coconino Plateau is defined largely by the geology and geologic structure that underlie the area (figs. 2 and 3). To the north the Colorado River has exposed a nearly 5,000 ft thick sequence of Precambrian to Paleozoic rocks. The Precambrian rocks are granite, metamorphosed granite, schist, and gneiss exposed in deeply incised canyons tributary to the Colorado River (Beus and Morales, 1990) and at the upper end of the Big Chino Wash (Reynolds, 1988). The Precambrian rocks have low permeability and are considered a basal confining layer to ground-water systems on the Coconino Plateau (Metzger, 1961; Twenter and Metzger, 1963; Bills and others, 2000). The Paleozoic rocks are sandstone, siltstone, shale, and limestone and range in age from early Cambrian to Permian. These rocks underlie almost the entire area and are exposed in deep canyons along the Colorado River to the north (Beus and Morales, 1990) and the Mogollon Rim to the south (Twenter and Metzger, 1963). The Paleozoic rocks contain most of the principal ground-water flow systems that occur on the Coconino Plateau (Metzger,
1961; Twenter and Metzger, 1963; McGavock and others, 1986; Bills and others, 2000). The Permian Kaibab Formation forms the bedrock surface over much of the Coconino Plateau (Reynolds, 1988). In places, erosional remnants of the Triassic Moenkopi Formation dot the landscape as low mesas and hills (McGavock and others, 1986; Reynolds, 1988). Many valleys formed on the Kaibab Formation erosional surface have been filled with Cenozoic gravel and lacustrine deposits to depths of $100 \mathrm{ft}$ or more (Billingsley and others, 2000). Cenozoic travertine is notable in some of the larger drainages. Travertine is still being deposited in Havasu Creek and the Little Colorado River (Cooley, 1976; Marx, 1995). On the southwestern part of the Coconino Plateau, the Paleozoic rocks are overlain by Triassic and younger sedimentary rocks, which are overlain in places by volcanic rocks of the Mt. Floyd and San Francisco Peaks Volcanic Fields (Billingsley and Hendricks, 1989).

The most notable structural features of the Coconino Plateau are the Havasu Downwarp, the Kaibab Monocline, the Mesa Butte Fault, the San Francisco Volcanic Field, the Aubrey Cliffs, the Mogollon Rim, and breccia pipes (figs. 1 and 2). The Havasu Downwarp is a structural trough that trends northwest to southeast down the axis of the Cataract Creek drainage. The trough is the result of regional compression during the Laramide orogeny that also was responsible for the broad regional uplift of the plateau (Krantz, 1989). The area is still seismically active (Fellows, 2000). There are also several topographically closed basins within the Coconino Plateau study area (fig. 1). These closed basins are thought to be related to still-active crustal extension occurring in the area, or to young karst development (Billingsley and others, 2000), and could significantly influence the ground-water flow systems. Much of the eastern edge of the Coconino Plateau is defined by a series of parallel to sub-parallel monoclines and faults falling off to the east (Metzger, 1961; Cooley and others, 1969; and Cooley, 1976). The most prominent of these are the East Kaibab Monocline, Mesa Butte Fault, and Echo Cliffs Monocline that have a combined relief of more than 3,000 ft (figs. 2 and 3). The Mesa Butte Fault that trends northeast-southwest is an extension of the East Kaibab Monocline at the eastern edge of the Kaibab Uplift (Shoemaker and others, 1978). This structure is Laramide in origin and is a principal structural feature at the eastern edge of the 

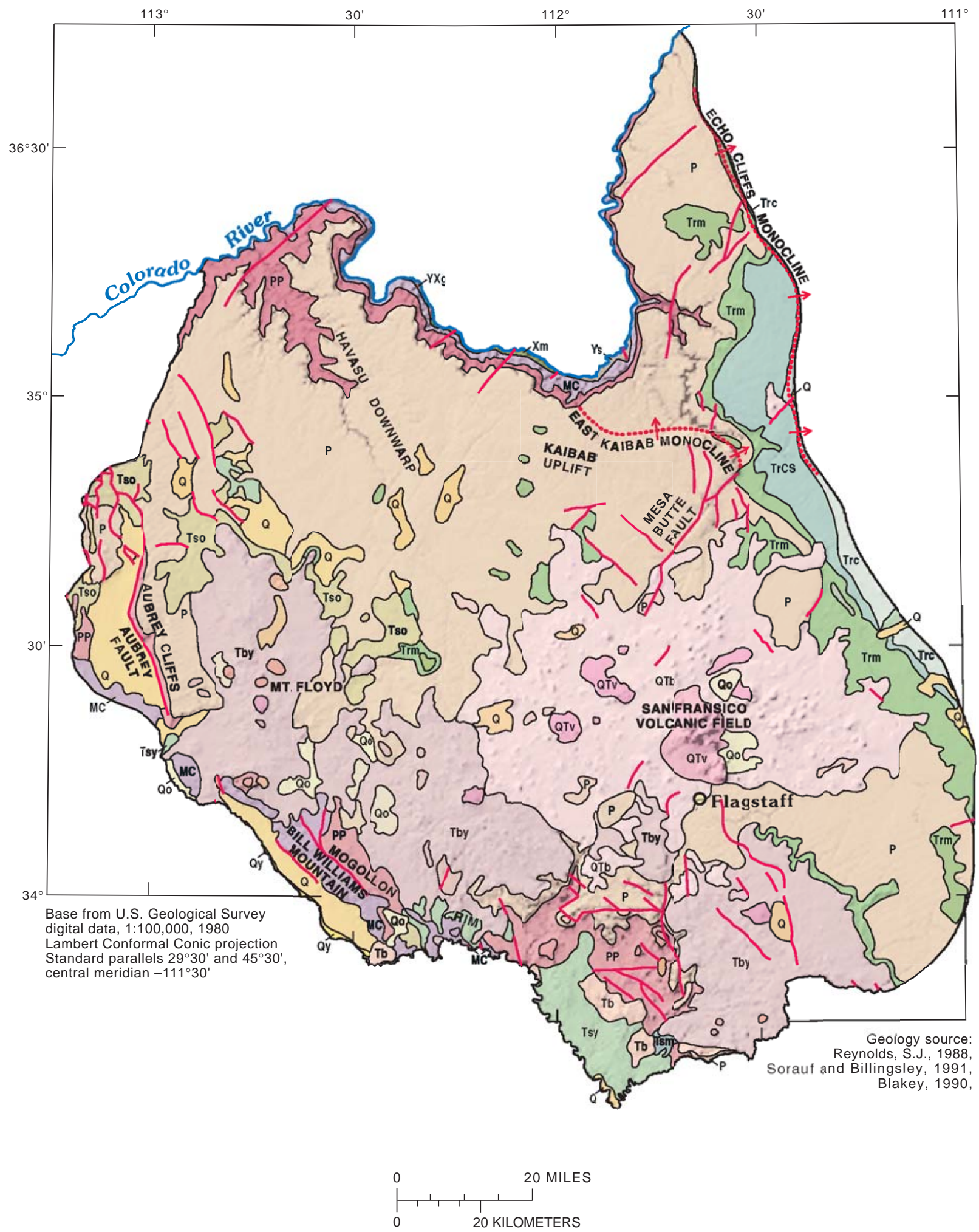

Figure 2. Surface geology and geologic structure of the Coconino Plateau, Arizona. 


\section{EXPLANATION}

Qy YOUNG ALLUVIUM-Holocene to latest Pleistocene. Deposits in present-day river and stream channels, flood plains, and playas

Q SURFICIAL DEPOSITS-Holocene to middle Pleistocene. Alluvium in present-day valleys and piedmonts, lacustrine and eolian deposits, and local glacial deposits

Qo OLDER SURFICIAL DEPOSITS-Middle Pleistocene to latest Pliocene. Alluvium with less abundant talus and eolian deposits

QTb BASALTIC ROCKS-Holocene to late Pliocene, 0 to 4 million years of age

QTV VOLCANIC ROCKS-Quaternary to late Pliocene. Rhyolitic to andesitic rocks associated with unit QTb

Tsy SEDIMENTARY ROCKS-Pliocene to middle Miocene. Units deposited during and after late Tertiary normal faulting, commonly capped by patches of Quaternary surficial deposits

Tby BASALTIC ROCKS-Pliocene to late Miocene; 4 to 8 million years of age

Tvy VOLCANIC ROCKS-Pliocene to middle Miocene; 4 to 15 million years of age. Rhyolitic to andesitic rocks associated with units Tby and Tb

Tb BASALTIC ROCKS-Late to middle miocene; 8 to 16 million years of age. Units erupted after most mid-Tertiary volcanism and tectonism

SEDIMENTARY ROCKS-Middle Miocene to Oligocene; 15 to 38 million years of age. Deposited during mid-Tertiary orogenic activity in the southwestern Transition Zone

Tso SEDIMENTARY ROCKS-Oligocene to Eocene or locally Paleocene. Units deposited on the Colorado Plateau and Transition Zone prior to or during the initial phases of mid-Tertiary volcanism; many units were deposited by drainage flowing north and east onto the Colorado Plateau; includes "rim gravels" and associated finer grained rocks along the Mogollon Rim; some units, especially those along the Tansition Zone, may overlap in age with unit Tsm

CHINLE FORMATION-Late Triassic. Shinarump Conglomerate Member (TrCS), Keyenta and Moenave Formations, and Wingate Sandstone

TrCS SHINARUMP CONGLOMERATE MEMBER

P SEDIMENTARY ROCKS - Kaibab Formation, Toroweap Formation, and Coconino Sandstone on the Colorado Plateau; age-equivalent rocks in the Basin and Range Province and Transition Zone are included with unit PP

SEDIMENTARY ROCKS-Schnebly Hill Formation, Hermit Formation, Supai Group, and Naco Group

PERMIAN AND $\zeta$ PENNSYLVANIAN

SEDIMENTARY ROCKS-Redwall Limestone, Muav Limestone, Martin Limestone, Temple Butte Limestone, and Tonto Group in northern Arizona

Ys SEDIMENTARY ROCKS - Middle Proterozoic. Grand Canyon Supergroup (locally late Proterozoic) and local basalt flows and diabase

YXg GRANITOID ROCKS-Middle or early Proterozoic; 1,400 or 1,650 to 175 million years of age

Xm METAMORPHIC ROCKS-Early Proterozoic; 1,650 to 1,800 million years of age. Undifferentiated metavolcanic and gneissic rocks

Figure 2. Continued. 


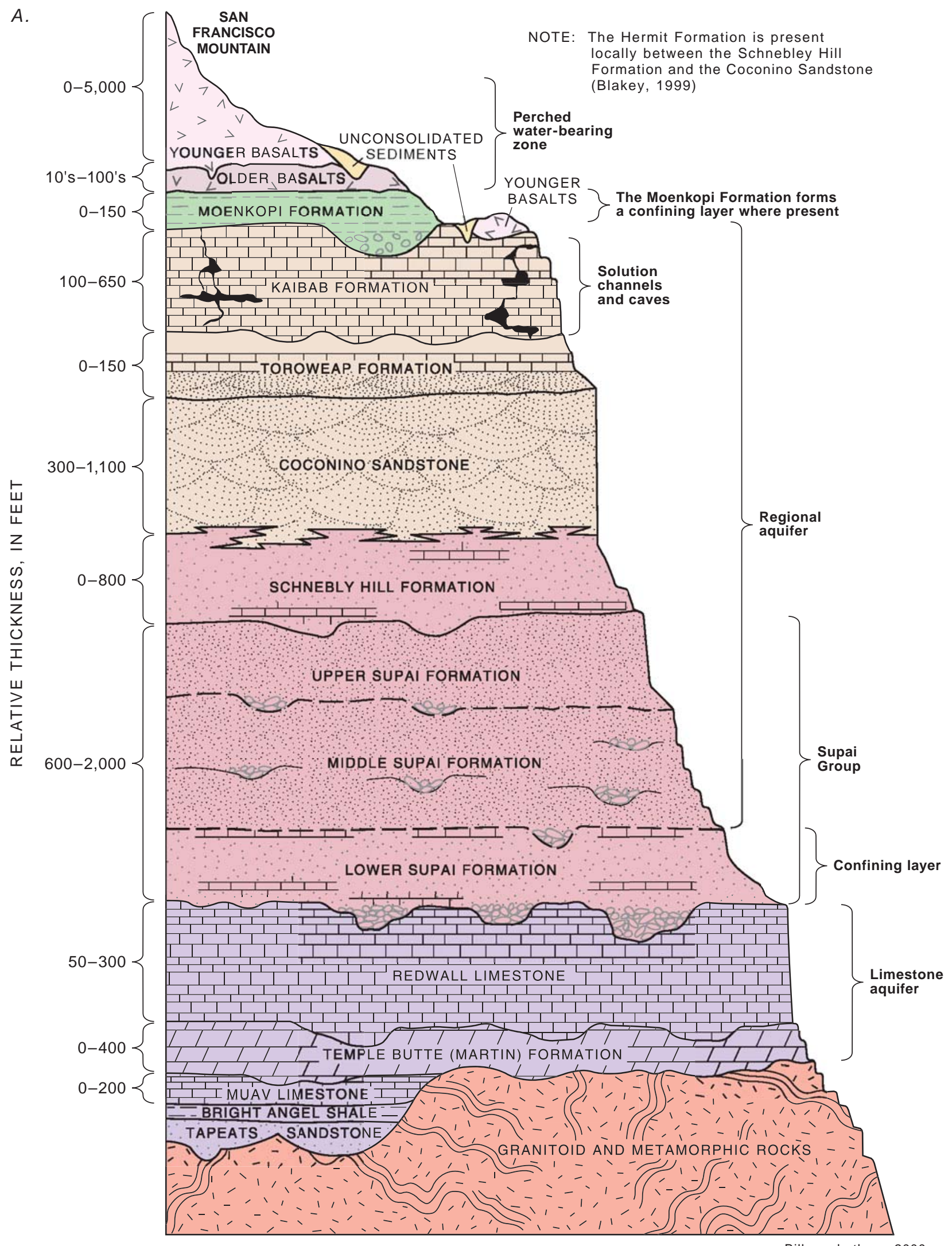

Bills and others, 2000

Figure 3. Generalized stratigraphic section and cross section of the Coconino Plateau, Arizona. 
$B$.

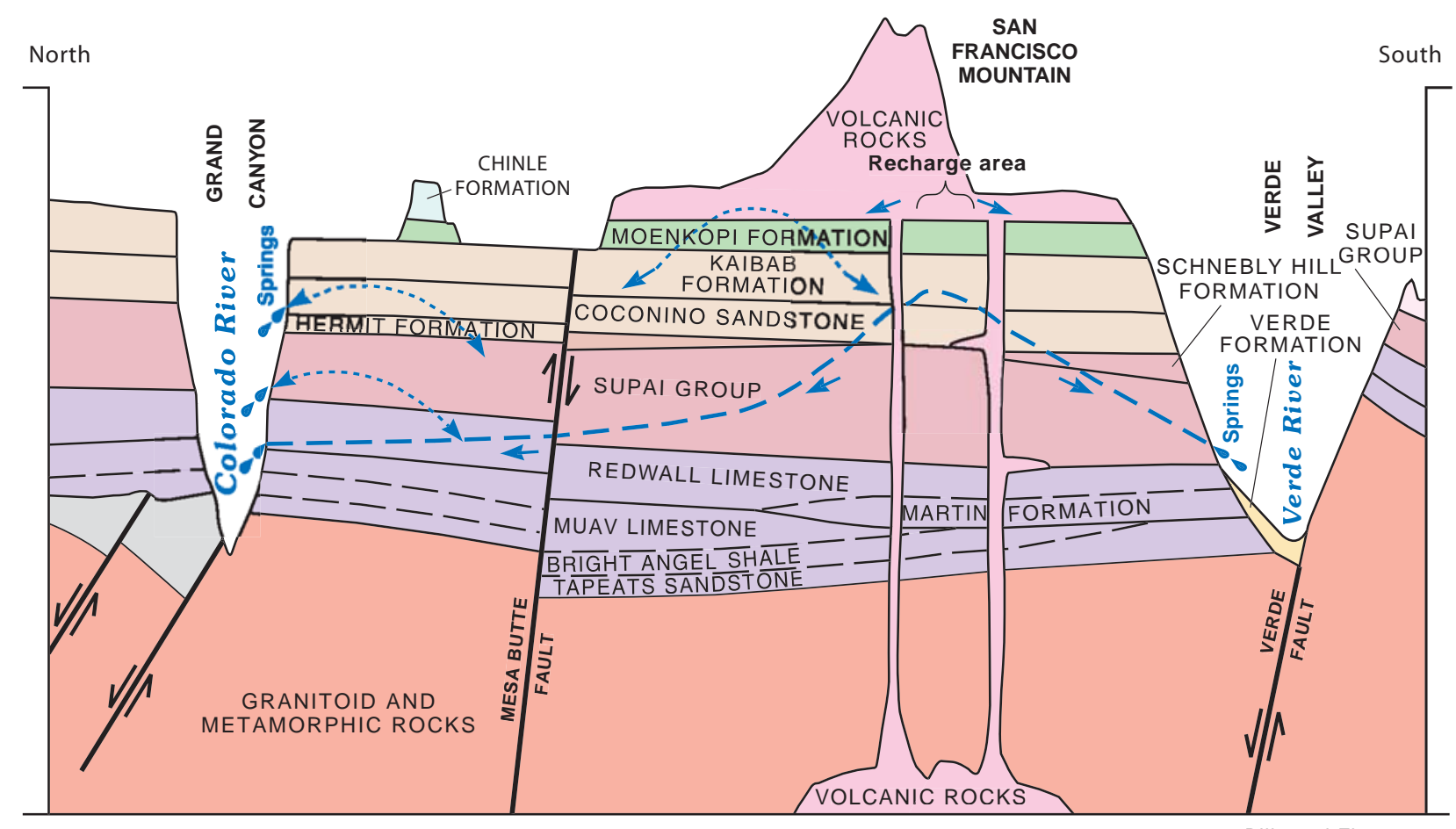

Bills and Flynn, 2002

\section{EXPLANATION}

SURFICIAL DEPOSITS; VERDE FORMATION

YOUNGER BASALTIC ROCKS

VOLCANIC ROCKS

CHINLE FORMATION

MOENKOPI FORMATION

SEDIMENTARY ROCKS-Kaibab Formation, Toroweap Formation, and Coconino Sandstone on the Colorado Plateau

SEDIMENTARY ROCKS—Schnebly Hill Formation, Hermit Formation, Supai Group, and Naco Group

SEDIMENTARY ROCKS—Redwall Limestone, Muav Limestone, Temple Butte (Martin) Formation, and Tonto Group

PRECAMBRIAN SEDIMENTARY ROCKS

GRANITOID AND METAMORPHIC ROCKS

- - REgional WATER tABle

-... PERCHED WATER-BEARING ZONE

$\leftarrow$ DIRECTION OF GROUND-WATER FLOW

$\leftrightharpoons$ FAULT-Arrows indicate direction of movement

Figure 3. Continued. 
Coconino Plateau. The San Francisco Volcanic Field covers most of the southern third of the Coconino Plateau stretching from Bill Williams Mountain in the west to San Francisco Mountain in the east. The volcanic field is from 6.0 to 0.05 million years old with a linear age trend from west to east (Nealey and Sheridan, 1989). The Aubrey Cliffs are the surface expression of the normal Aubrey Fault. The sedimentary rocks on the east side of the fault are uplifted $500 \mathrm{ft}$, exposing parts of the Hermit Shale and Upper Supai Formation at the base of the cliffs (Billingsley and others, 2000). South of and partly obscured by the San Francisco Volcanic Field is the Mogollon Rim. The Mogollon Rim is a 2,000 ft escarpment that exposes more than $3,000 \mathrm{ft}$ of the Paleozoic and younger rock units at the southern edge of the study area above the Verde River Valley (Pierce, 1984) and trends northwest to southeast through the southern end of the study area. Breccia pipes are solution collapse features that bottom in the Redwall Limestone and stoop upward and number in the hundreds throughout the Coconino Plateau (Billingsley and others, 2000). Because of the small size and large number of these features, they are not shown on any of the illustrations in this report. Breccia pipes are significant features, however, owing to their relation to ground-water movement and to secondary mineralization, which may influence water chemistry (Wenrich and others, 1994).

Drainages on the Coconino Plateau are either immature, mature, or internal (fig. 1). Most of the immature drainages are at the margins of the Coconino Plateau and drain north toward the Colorado River or south toward the Verde River. These immature drainages are short and steep and tend to be deeply incised into the sedimentary rocks. Springs exist along these drainages where the channels intersect the water table or a perched water-bearing zone. The only drainages that have the appearance of mature river valleys are the Little Colorado River, Cataract Creek, and the Verde River. These drainages have large, welldeveloped tributary drainage patterns that reach most parts of the Coconino Plateau (fig. 1). Some internal drainage on the Coconino Plateau occurs in topographically closed basins.

Altitude and climate are strongly correlated within the study area (figs. 4 and 5; McGavock and others, 1986; Bills and others, 2000). Altitude within the study area ranges from 12,633 ft at the top of San Francisco Mountain to $1,730 \mathrm{ft}$ at the confluence of National
Canyon and the Colorado River. Altitudes along the upper and middle Verde River to the south range from about 3,500 to 4,400 ft. The Coconino Plateau in northcentral Arizona is dominated by a high, desert-type environment with islands of alpine environments at the higher altitudes. The average annual temperature ranges from $43{ }^{\circ} \mathrm{F}$ at Fort Valley on the southwest flank of San Francisco Mountain to $68^{\circ} \mathrm{F}$ at Phantom Ranch at the bottom of Grand Canyon (Sellers and others, 1985). The average annual precipitation for the area ranges from $5.5 \mathrm{in}$. at Cameron at the eastern edge of the area to $27.7 \mathrm{in}$. at Junipine (Sellers and others, 1985). Precipitation is strongly correlated to altitude; generally less than 15 in. per year falls at altitudes below 5,000 ft, and more than $25 \mathrm{in}$. per year falls at altitudes above 7,000 ft (fig. 5; McGavock and others, 1986; Bills and others, 2000).

Ponderosa pine forest with piñon and juniper pine, aspen, and oak is the primary vegetation type at higher altitudes. Vegetation at lower altitudes is mostly sparse grasses, brush, and other high desert species. Riparian habitat consisting of a diverse mixture of cottonwood, ash, and sycamore with mixed brush and grass occurs throughout the Coconino Plateau at springs, seeps, and along short stream segments fed by springs (Metzger, 1961; Bills and others, 2000).

\section{Population Growth and Land Use}

Over the past decade, the rate of population growth and development on the Coconino Plateau has been equal to and in some cases exceeded that for the rest of the State of Arizona (Kasindorf and McMahon accessed, April 24, 2001). The population of the study area increased 20 percent from 1990 to 2000 and is currently about 78,000; about 80 percent live in the Flagstaff area (U.S. Census Bureau accessed, April 24, 2001). About 5 percent of the population lives at the western end of the Navajo Reservation and on the Havasupai Reservation. The remainder of the population lives in smaller population centers, such as Williams, Valle, Tusayan, Grand Canyon Village, Parks, and in rural areas throughout the study area. The Verde Valley area south of the Mogollon Rim was one of the fastest growing rural areas in the United States in 1999 (Woods and Poole Economics, Inc., 1999), and the population is projected to more than double by 2050. 

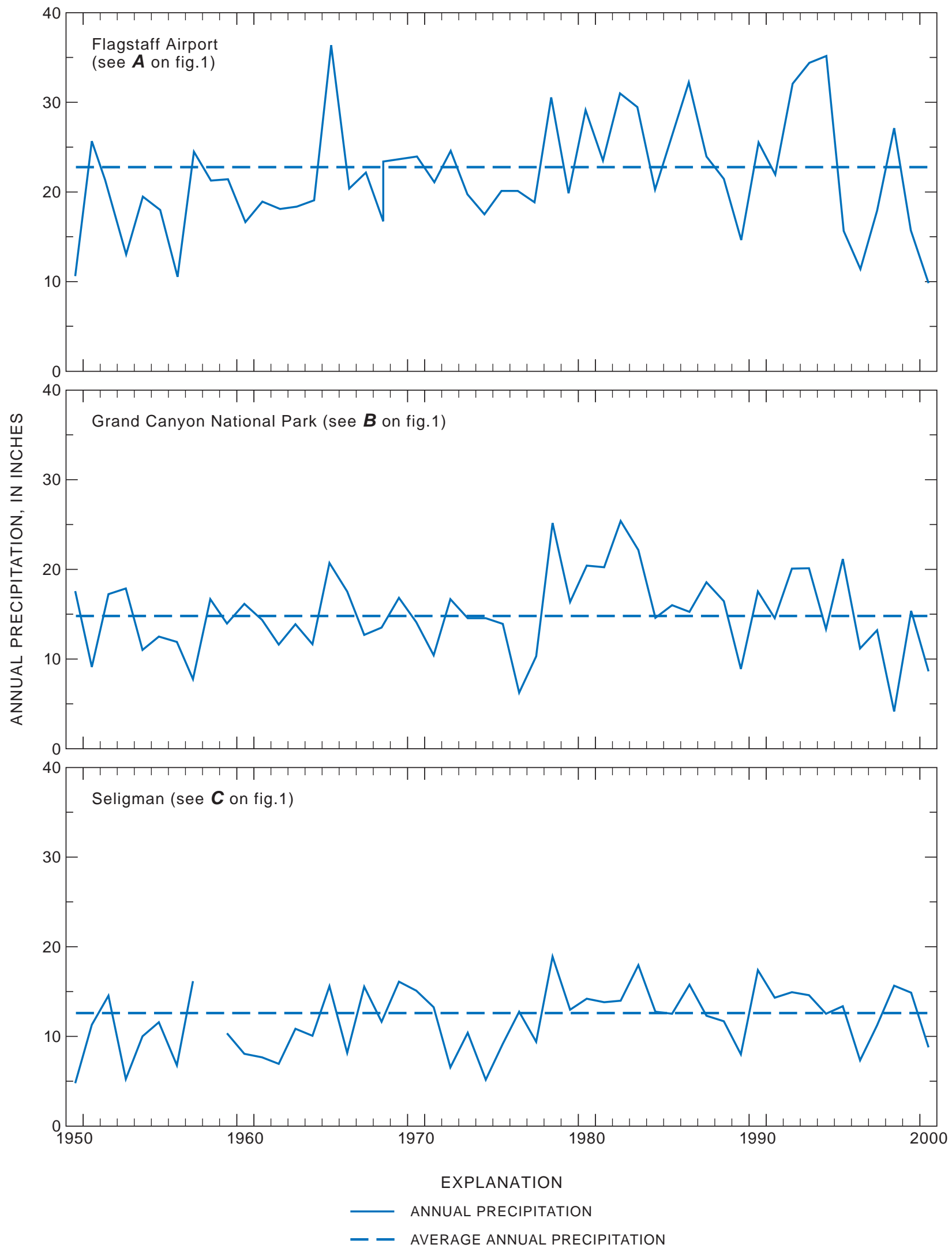

Figure 4. Average annual precipitation at selected precipitation stations on the Coconino Plateau, Arizona. 


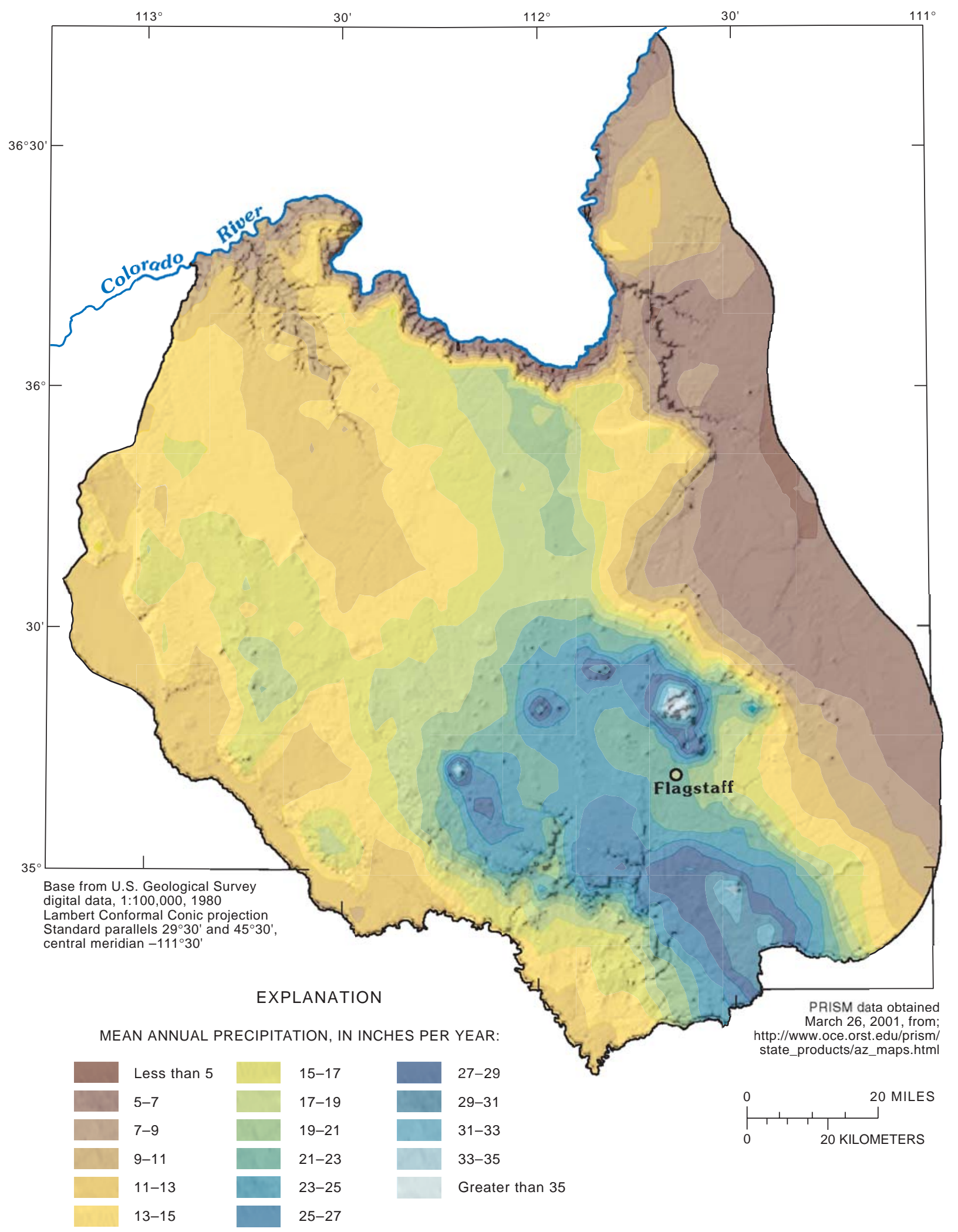

Figure 5. Mean annual precipitation on the Coconino Plateau, Arizona. 
In addition, northern Arizona attracts millions of visitors each year to one of the largest concentrations of national parks and monuments in the western United States (Ghioto, 2001). Chief among these is Grand Canyon National Park (GCNP), which is designated a World Heritage Site and is one of the seven natural wonders of the world (National Park Service accessed, April 2001). Currently, 4.5 to 4.9 million people visit GCNP each year (Ghioto, 2001). Although GCNP visitation fluctuates, the average rate has increased annually by about 6 percent since 1985, and at least 90 percent of this visitation occurs at the south rim of GCNP (Ghioto, 2001).

The Coconino Plateau study area includes multiple jurisdictions including the Kaibab and Coconino National Forests, GCNP, the Havasupai Indian Reservation, the Navajo Indian Reservation, Navajo and Hopi Tribal trust lands, State of Arizona trust land, and private ownership. According to the Arizona State Land Department (1998), about 42 percent of the land in the study area is federally owned as national forests, parks, and monuments. About 20 percent of the land is included in Indian reservations or native trust lands, and 38 percent is about evenly split between State trust and privately owned lands. The water-demand and water-supply issues of these different jurisdictional areas are the principal reason for the current interest in the availability and sustainability of regional water resources.

\section{Water Resources}

Ground-water resources consist of several perched water-bearing zones, a regionally extensive aquifer, and a limestone aquifer (fig. 3b). The extent of these ground-water systems is not fully defined, and there is little information to determine movement of water from source areas into and through the different waterbearing zones to discharge areas. There are few perennial streams in the study area, but many short perennial reaches are supported by ground-water discharge (McGavock and others, 1986). Flow and chemistry information exists only for the larger perennial streams.

Perched water-bearing zones provided some of the first water supplies in the study area. The first successful wells drilled in the area were shallow wells completed in perched water-bearing zones near the larger communities and ranches (Harshbarger and
Associates and John Carollo Engineers, 1972). Some of the original water supplies in the mid- to late $1800 \mathrm{~s}$ were a few small, perched-aquifer springs close to the developing cities of Flagstaff and Williams (Bills and others, 2000; Dennis Dalbeck, City Manager, City of Williams, oral commun. 2000). Springs along the south rim of GCNP also were used to support tourism and mining in the late 1800s and early 1900s (Billingsley and others, 1997; and John Rihs, Hydrologist, Grand Canyon National Park, oral commun. 2001). Ground water discharges from perched water-bearing zones in alluvium, the Kaibab Formation, the Coconino Sandstone, and the Upper and Middle Supai Formations throughout the interior of the Coconino Plateau (fig. 6). Most of these perched water-bearing zones are small, discontinuous, and yield only small amounts of water, which limit their use as sources of water supply (Metzger, 1961; McGavock and others, 1986). Many springs and seeps also occur in the higher elevations of the Coconino Plateau where they emit from perched water-bearing zones in alluvium, volcanic rocks, and consolidated sediments (McGavock and others, 1986; Bills and others, 2000).

As water use in the area began to exceed these less dependable near-surface water resources, exploratory drilling led to the discovery of ground water in the Paleozoic sandstones that underlie the study area (Harshbarger and Associates and John Carollo Engineers, 1972). The first municipal supply wells, drilled into what was then called the Coconino aquifer, were developed in the 1950s. The regional aquifer as it is currently defined (Bills and others, 2000) consists of hydraulically connected water-bearing zones in the Kaibab Formation, Coconino Sandstone, Schnebly Hill Formation, and sandstone units in the Upper and Middle Supai Formations (Bills and others, 2000). Several investigators have suggested drainage from the regional aquifer to an underlying limestone aquifer in the northern part of the study area is related to geologic structure (Cooley and others, 1969; McGavock and others, 1986; Bills and others, 2000).

This limestone aquifer is composed of waterbearing zones in the Redwall and Muav Limestones, and in the Martin/Temple Butte Formation and Devonian Limestones where present (Metzger, 1961; Cooley and others, 1969). The first successful well completed in water-bearing zones of the limestone aquifer (the Redwall and Muav Limestones) was a test well for the City of Flagstaff drilled in 1981 to a total depth of about 3,400 ft (Montgomery, 1981). Since 


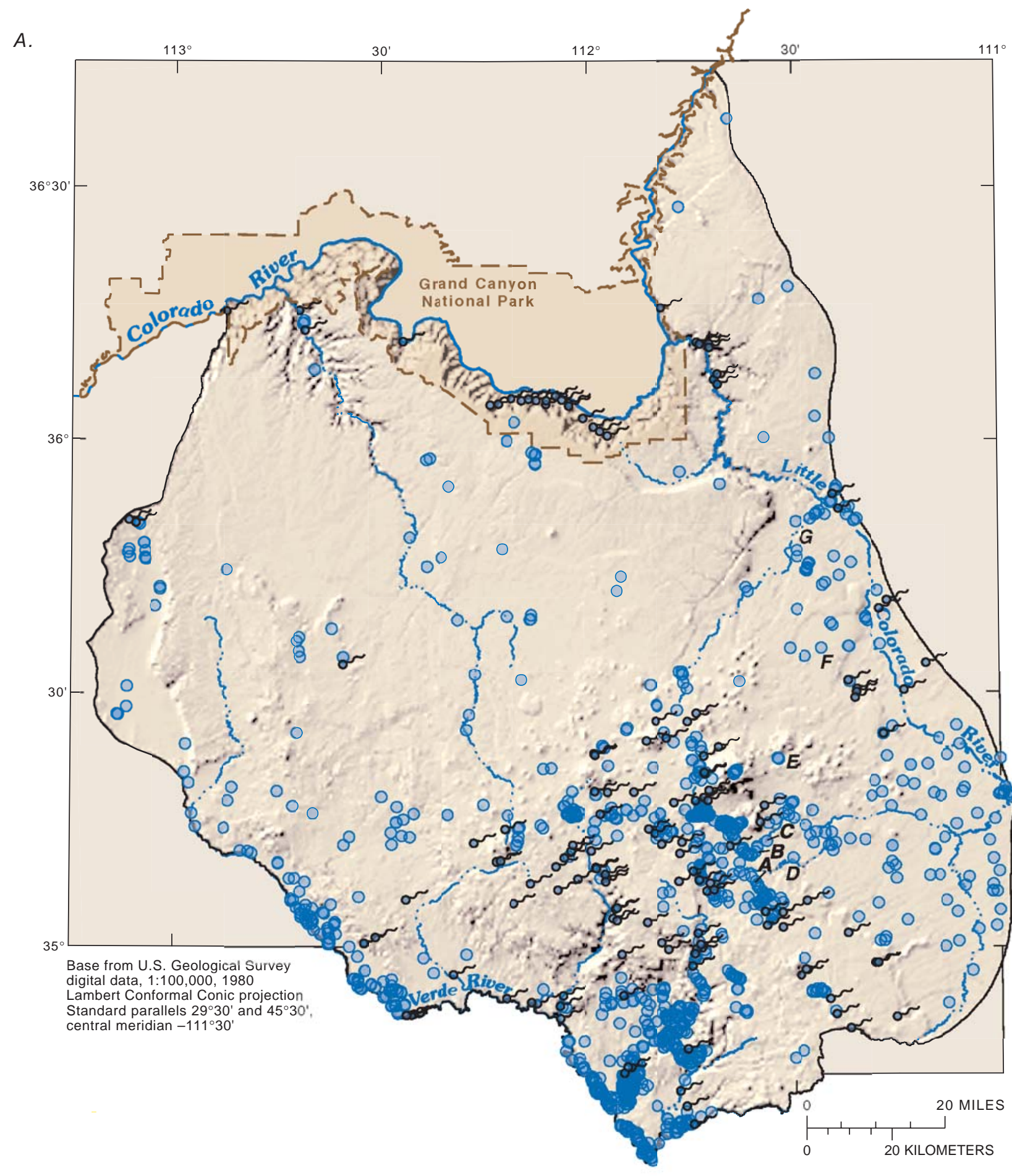

\section{EXPLANATION}

- WELL-Lettered wells correspond to hydrograph on facing page

Figure 6. Locations of wells and springs, and hydrographs showing depth to water in selected wells, Coconino Plateau, Arizona. 


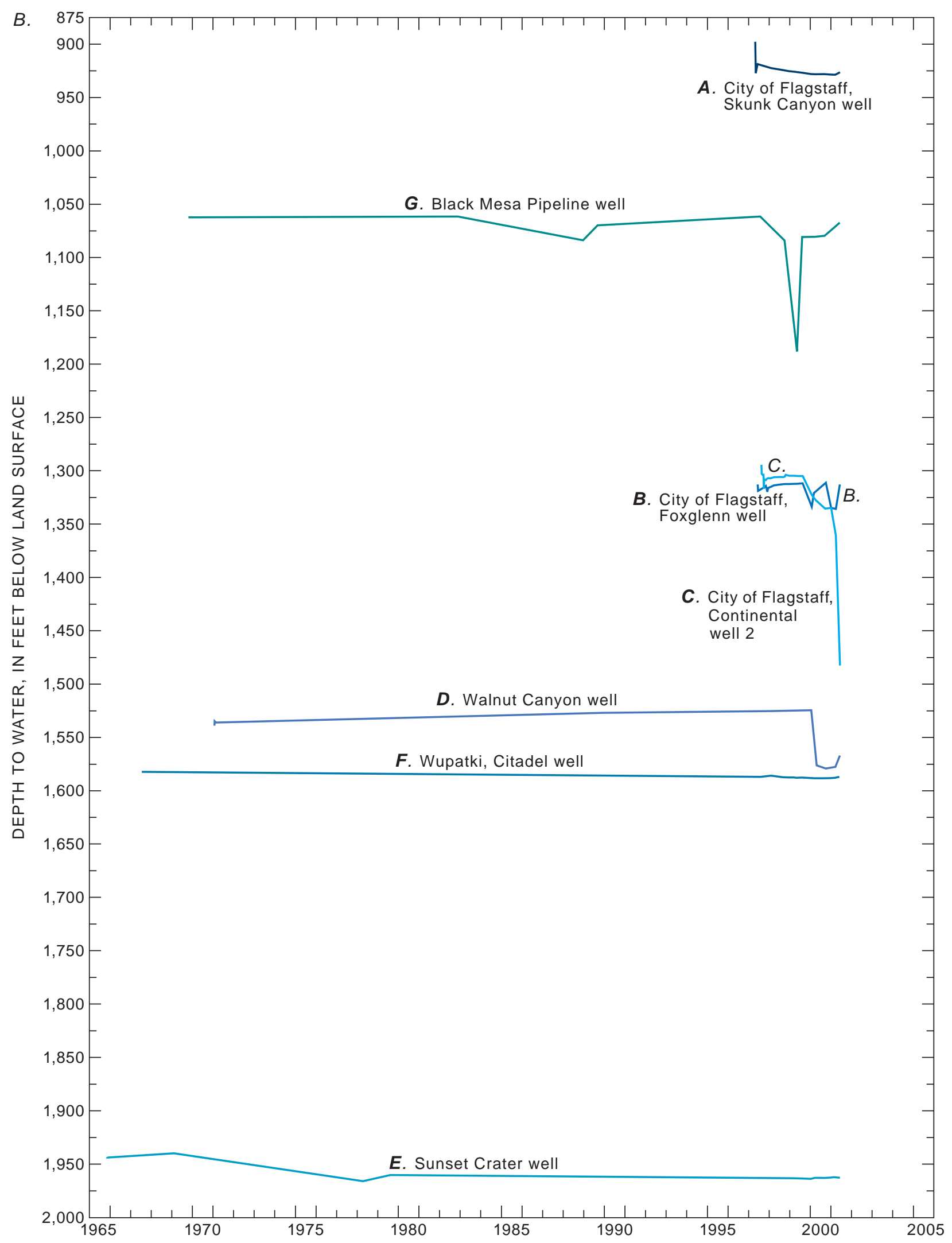

Figure 6. Continued. 
then, 10 water wells have been drilled into the Redwall and Muav Limestones at similar depths for public supply, commercial development, or industrial use on the Coconino Plateau. Little is currently known about the yield of these newer wells or the hydraulic characteristics of the limestone aquifer in proximity of these wells. Depth to water in the limestone aquifer is greater than $3,000 \mathrm{ft}$ below land surface in most of the study area.

Springs have been used and developed as an important source of water supply in the study area since antiquity (Roland Manakaja, Director, Havasupai Natural Resources Department, oral commun., 2001; Paul Whitefield Natural Resources Specialist, Wupatki National Monument, oral commun., 2001). South rim springs, springs in the Havasu Creek Basin, and other springs throughout the Coconino Plateau have been and continue to be important physical and cultural resources for the native people of the region (Kaibab National Forest, 1999). Locally, large and small springs supply water for livestock, wildlife, and riparian habitat. Regionally, larger springs provide base flow in streams and are used for public supply, agriculture, and recreation (McGavock and others, 1986). Blue Springs, Havasu Spring, Indian Garden, Hermit Spring, and at least 30 other springs at the north end of the study area emit from water-bearing zones in the Redwall and Muav Limestones into tributary canyons of the Grand Canyon that are about 3,000 feet below the mean elevation of the Coconino Plateau. Other springs emit from water-bearing zones in the Upper and Middle Supai Formations and the Redwall and Muav Limestone that are exposed in drainages flowing south from the Mogollon Rim into the Verde Valley, such as Oak Creek Canyon, Sycamore Canyon, and Hell Canyon (Twenter and Metzger, 1963).

Surface-water resources of the Coconino Plateau also are an important part of the natural environment of the study area. The perennial Colorado and Verde Rivers bound and drain the Coconino Plateau to the north and south, respectively. The only other perennial streams of significant length are the lower $13 \mathrm{mi}$ of the Little Colorado River; Havasu Creek, downstream of Havasu Springs; and Oak Creek. All other drainages in the area are ephemeral; a few short perennial reaches are supported by spring discharge (fig. 1).

Errol L. Montgomery and Associates (1999) have evaluated available ground-water data for a large part of the study area and developed a two-dimensional ground-water flow model to estimate potential effects of ground-water withdrawal for the Tusayan Growth Environmental Impact Statement. Their report indicates a direct relation between ground-water pumping and spring flows in areas where ground water discharges from the regional aquifer in the northern part of the plateau. Wilson (2000) used a geologic framework model and three-dimensional ground-water flow model to delineate capture zones for three of the major spring areas along the south rim of Grand Canyon. Additional work is in progress by Northern Arizona University, the Havasupai Tribe, the USGS, and the NPS. Northern Arizona University is conducting studies to define spring discharge along the south rim of Grand Canyon and delineate additional capture zones for these spring areas (A.E. Springer, Ph.D., professor, Northern Arizona University, oral commun., 2000). The Havasupai Tribe has inventoried springs on the Havasupai reservation and adjacent areas and continues to collect water-resources data (Natural Resources Consulting Engineers, Inc., 1999, 2000). The USGS and the NPS monitor selected springs and are in the process of inventorying and measuring flow at all springs along the south rim of Grand Canyon (S.A. Monroe, Hydrologic Technician, USGS, oral commun., 2000).

\section{AVAILABLE DATA}

Existing hydrogeologic data were compiled from October 2000 through September 2001 for this report. These data include information on climate, geology, ground water, surface water, water chemistry, land use, vegetation, and water use (tables 2-4, 6 and 7; figs. 2, 3, 5-11). Some new wells and unsurveyed springs also were inventoried as part of this data compilation. These data are from deep wells drilled in the Williams and Flagstaff areas and from selected unsurveyed springs along the south rim of Grand Canyon. Climate, groundwater, surface-water, water-chemistry and water-use data are provided on the compact disc at the back of this report and are available in electronic form from the USGS District office in Tucson, Arizona. Geology, land-use, and vegetation data are in maps in digital and paper form derived from remote-sensing techniques and standard geologic mapping. New data will be added to this base of information as the study continues, as part of the Arizona RWI, to further define the hydrogeologic framework of the Coconino Plateau. 


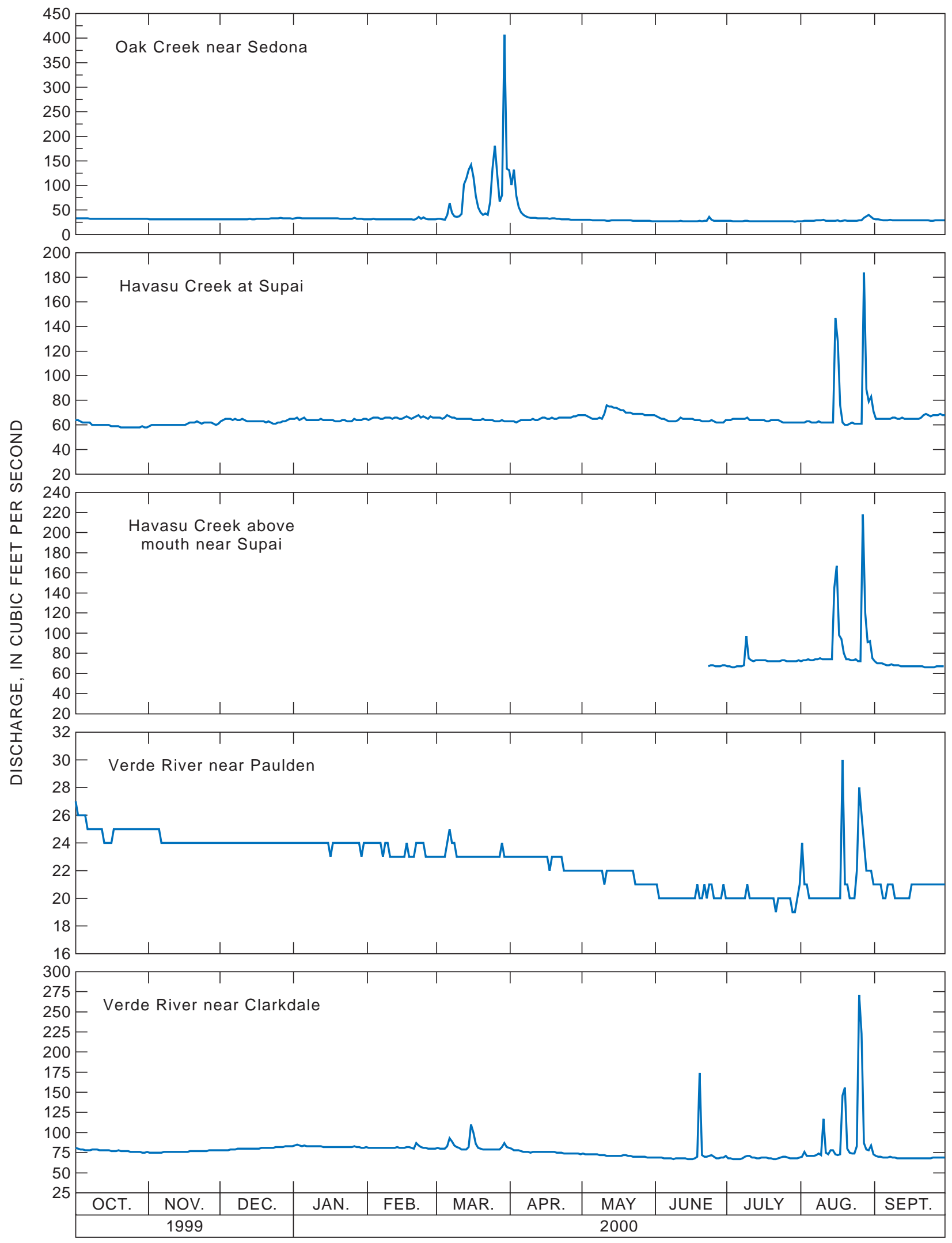

Figure 7. Discharge at selected streamflow-gaging stations on the Coconino Plateau, Arizona. 


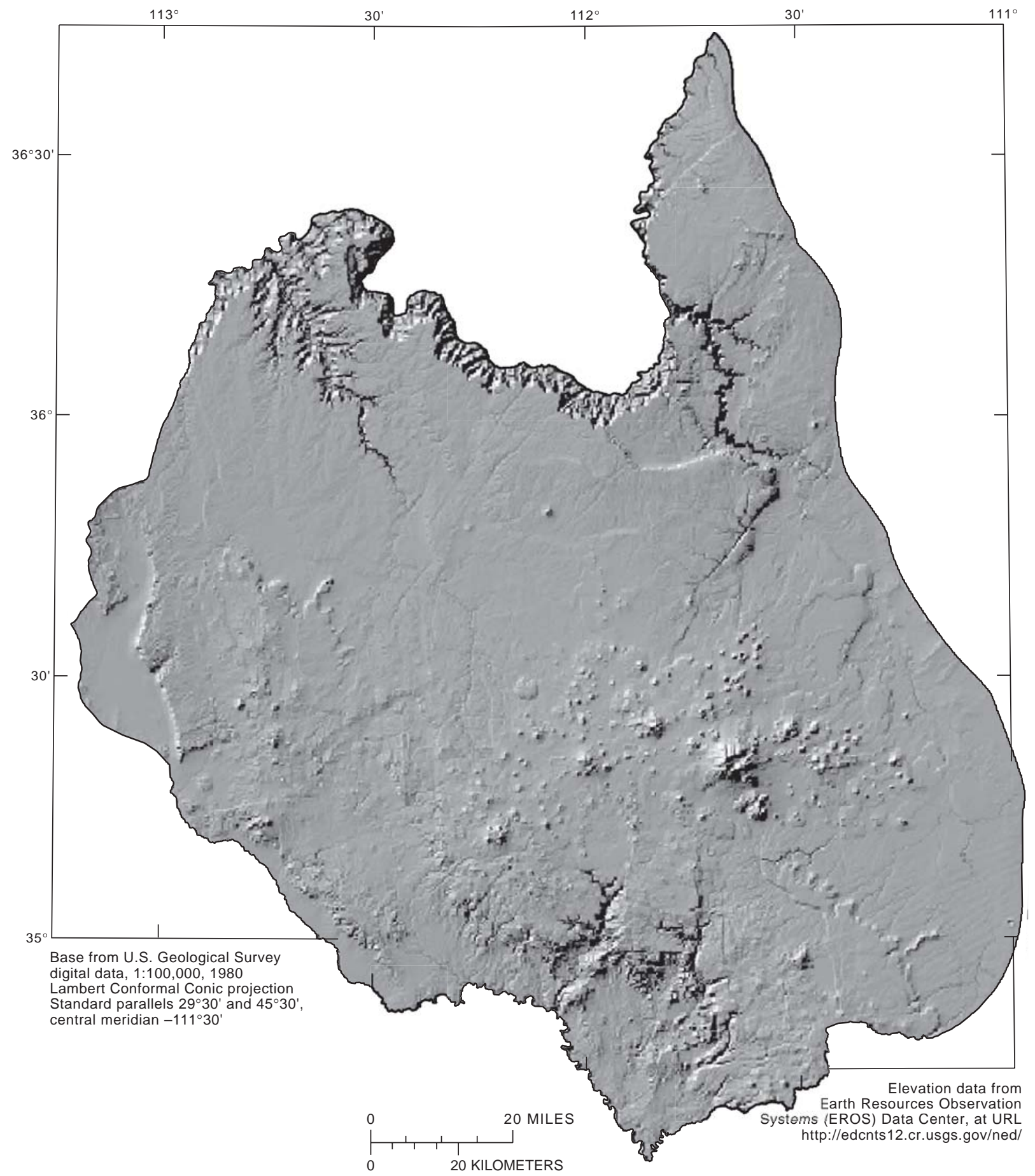

Figure 8. Shaded relief digital elevation model for the Coconino Plateau study area, Arizona. 


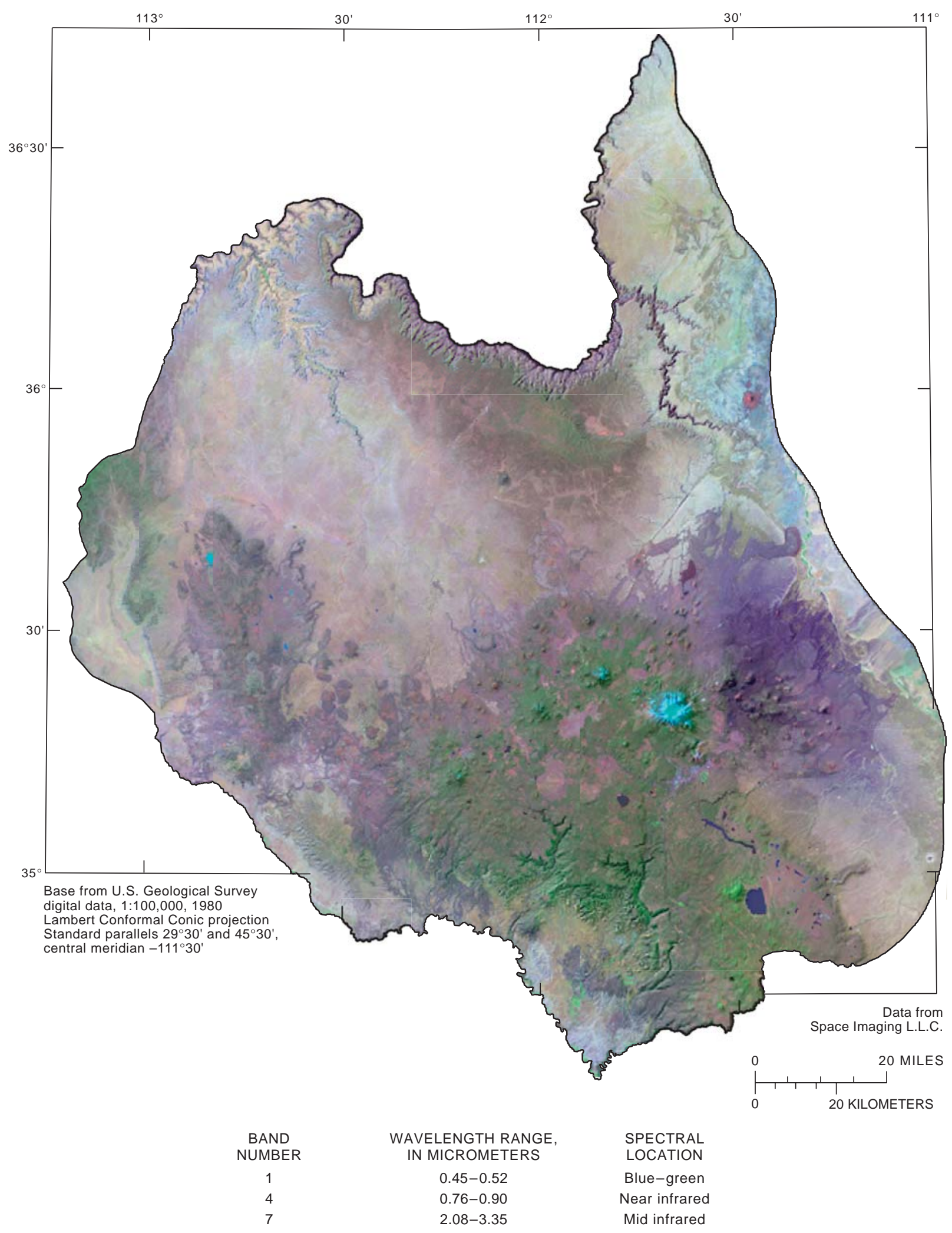

Figure 9. Remotely sensed infrared image of the Coconino Plateau study area, Arizona, using Thematic Mapper bands 1, 4, and 7, June 1993. 


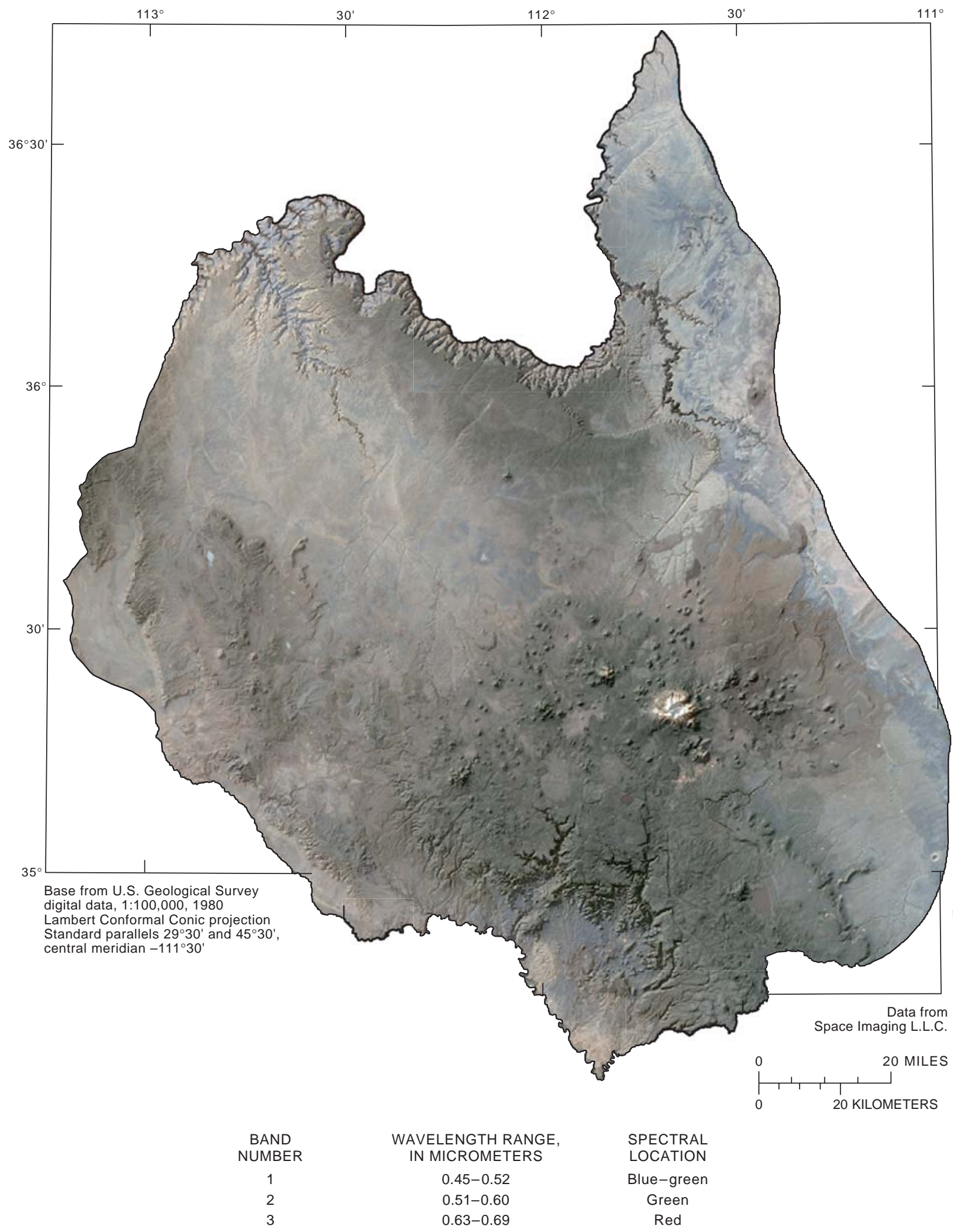

Figure 10. Remotely sensed visible color image of the Coconino Plateau study area, Arizona, using Thematic Mapper bands 1, 2, and 3, June 1993. 


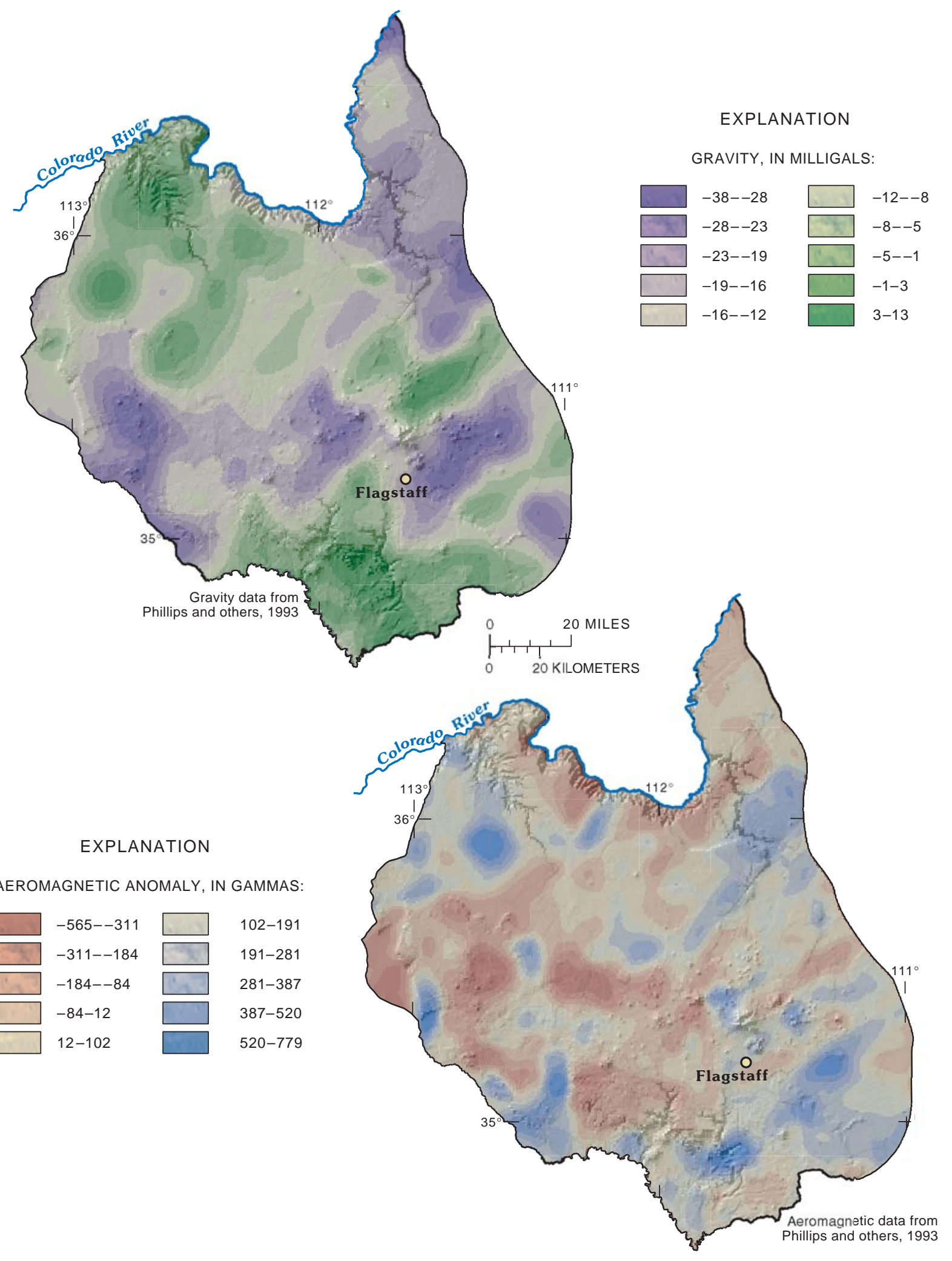

Figure 11. Isostatic residual gravity and aeromagnetic anomaly data for the Coconino Plateau study area, Arizona. 


\section{Climate Data}

Most of the climate data available for the study area were obtained from the National Weather Service. There are 36 reporting stations within the study area, and 17 of those are currently active (fig. 1, table 6). The period of record for these sites ranges from 3 years at the Bellmont National Weather Service Office near Flagstaff to 89 years at Fort Valley northwest of Flagstaff. Recorded temperature and precipitation data are available for all the sites in the study area. Recorded evaporation data are available for only one site (Grand Canyon NP2). The distribution of sites throughout the study area is fair; the poorest data availability is in the northwestern part. Most sites have adequate periods of record for statistical analysis. Annual recorded precipitation and average annual precipitation for selected sites are shown on figure 4 .

Additional precipitation data were obtained from a statistical-geographical approach model developed at Oregon State University called PRISM (ParameterElevation Regressions on Independent Slopes Model, fig. 5; Daly and others, 1994). PRISM uses DEM data that contain information describing the Earth's topography (slopes, aspects, and elevations) and observed precipitation measurements to determine variations in precipitation as a function of elevation (Daly and others, 1994). PRISM uses a regression model to extend point data from weather stations to the entire area of interest. These estimates are derived from a horizontal grid and are compatible for use in geographic information systems.

\section{Geologic Data}

The general geology and geologic structure of the region is known or inferred from more detailed geologic investigations in adjacent areas (Cooley and others, 1969; Ulrich and others, 1984; Wolfe and others, 1987; Nealey and Sheridan, 1989; Newhall and others, 1987; Huntoon and others, 1986; Huntoon and others, 1981 and 1982; Wenrich and others, 1997; Billingsley and others 2000). The level of detailed geologic information found in these adjacent areas, however, is generally lacking for large parts of the Coconino Plateau (fig. 2; Reynolds, 1988).

Geology and structural information in sufficient detail (minimally 1:100,000 scale) are important components of a hydrogeologic framework analysis.
Some parts of the Havasu Basin, the Coconino Plateau west of Cameron, and the Bill Williams Mountain area have yet to be mapped at this scale. The USGS is currently mapping areas between Grand Canyon and Williams, and between Grand Canyon and Flagstaff (George Billingsley, geologist, USGS, written commun., 2001).

\section{Ground-Water Data}

\section{Well Data}

Types and sources of existing well data collected and compiled for this report are summarized in table 1, and well locations and selected hydrographs are shown on figure 6 . The database created for this study has information on 1,767 wells. The USGS NWIS database contains information on 1,408 of those wells. The next largest source of information is the ADWR GWSI database that contains information on 360 wells not already in the USGS NWIS database. Other sources of well information for this study are NPS and Forest Service databases and information from private well owners, tribal well data (National Resources Consulting Engineers, 1999, 2000), and data from NAU and UNLV thesis studies (Goings, 1985; Zukosky, 1995; Fitzgerald, 1996; and Wilson, 2000). Table 2 presents general information on the wells including location, total depth, depth to water, well design, and whether borehole logs or additional information are available. Well depths range from a few feet to $6,500 \mathrm{ft}$ below land surface and well yields range from less than 1 to 1,293 gallons per minute (gpm; table 2). Figure 6 shows the location of wells on the Coconino Plateau and the location and temporal trends of water levels in selected wells. The criteria for selection of these observation wells were well construction and design and access for water-level measurements. Additional wells in areas where data are limited will be used as observation wells as they become available and access is obtained.

\section{Spring Data}

Of 295 springs mapped in the study area, 164 have been inventoried with reliable information on location, geologic unit, flow rate, and water chemistry. The USGS NWIS database contains, at a minimum, locational information on 188 springs. The next largest source of information is the Havasupai tribal data, 
which cover reservation springs. Other sources of spring information for this study are the ADWR GWSI, Forest Service, and the NPS databases and information from private and academic sources (table 1). Spring locations are shown on figure 6 . Spring flows range from less than 1 to more than $48,000 \mathrm{gpm}$ (Blue Spring; table 2).

\section{Surface-Water Data}

Streamflow data are available for 66 streamflow sites within the study area (fig. 1, table 3). Of these, 29 are continuous-record sites for flow with periods of record that range from 2 to 59 years, and 13 of these were active in the 2001 water year (October 2000 to September 2001). Figure 7 shows discharge at selected streamflow-gaging stations for the 2000 water year.

Peak-flow and partial-record discharge data were obtained for 32 sites within the study area; 4 of these are active sites. Most of this information is collected along the larger perennial streams in the area and near population centers such as the City of Flagstaff. There are little if any data available on flow and basin characteristics for many of the ephemeral streams and for topographically closed basins within the study area.

\section{Water-Chemistry Data}

The water-chemistry data include information for 22 streams, 156 springs, and 420 wells (table 4). The sources for these data are the USGS, the NPS, NAU and UNLV theses, and the Havasupai Tribe. Of 1,364 water samples analyzed, 1,090 were analyzed only for major cations and anions; 610 were analyzed for nutrients; 365 were analyzed for trace elements; and 120 were analyzed for radionuclides or isotopes.

Water chemistry is varied throughout the study area. Specific conductance values range from 8.0 to $20,200 \mu \mathrm{S} / \mathrm{cm}$, and dissolved solids range from 31 to $12,400 \mathrm{mg} / \mathrm{L}$. Alkalinity ranges from 26 to $483 \mathrm{mg} / \mathrm{L}$, and $\mathrm{pH}$ ranges from 5.8 to 10.8 . In 264 of the samples, some major ions, nutrients, trace elements, and radionuclides exceeded the U.S. Environmental Protection Agency (USEPA) Maximum Contaminant Levels (MCLs) or Secondary Maximum Contaminant Levels (SMCLs) for drinking water. Table 5 shows the constituents that exceeded USEPA MCLs or SMCLs at selected wells, springs, and surface-water sites.

\section{Remotely Sensed Data}

Digital elevation data with a resolution of one arcsecond (about 30 meters) were obtained from the Earth Resources Observations Systems Data Center as part of the National Elevation Dataset (U.S. Geological Survey, 2001a; fig. 8).

The entire study area is imaged with Landsat 7 Thematic Mapper (TM) data. The Landsat 7 TM satellite collects radiation data in seven electromagnetic spectral bands. Bands 1, 4, and 7 record data in the near and middle infrared parts of the spectrum (fig. 9). Bands 1, 2, and 3 record data in the blue, green, and red parts of the visible spectrum (fig. 10). These spectral band combinations were selected owing to their ability to enhance surface structural and vegetation information (Chavez and others, 1996). The ground resolution of these data is about $98.4 \mathrm{ft}$, but resampling provides a nominal resolution of about $10 \mathrm{ft}$. Landsat $7 \mathrm{TM}$ data, were acquired for two time periods, June 1993 and June 2000 (USGS, 2000d), in order to provide data for both wet and dry climatic conditions. As the data are classified to relate colors to spectral class and surface features, these images can be qualitatively analyzed to determine conditions in detail for small areas.

Black and white aerial photographs also were acquired for the entire study area. The photographs are part of the National Aerial Photograph Program and were taken during 1958 and 1972 (U.S. Geological Survey, 2000d). The scales of the photographs are $1: 34,000$ and $1: 30,000$, respectively, with a resolution of about 6 feet. Satellite and aerial photography can be used to determine land use, riparian areas, and geologic structure. Aerial photography is being used to facilitate ongoing geologic mapping in the study area (George Billingsley, Geologist, U.S. Geological Survey, oral commun., 2001).

Gravity and aeromagnetic data for this study were extracted from the national 2- and 3-kilometer grids of the USGS (fig. 11; Phillips and others, 1993) and registered to topographic data for display of the images. The gravity field of the Earth is equal to the theoretical sea-level acceleration at the equator of 32.2 feet per second per second. This unit is too large for geophysical work, so the milligal is used. One milligal is equal to $3.281 \times 10^{-5}$ feet per second per second. After the gravitational data are adjusted for latitude, altitude, tides, density, and instrument drift, gravity anomalies caused by differences in the density 
of different types of geologic material can be resolved. Aeromagnetic data are used to evaluate magnetic field anomalies caused by the magnetic fields of different types of rock and geologic structures superimposed on the Earth's magnetic field. The magnetic effects of rock are complex, having both magnitude and direction. Magnetic gradients near the edges of magnetic anomalies commonly indicate the location of geologic structures or contacts. Gravity and aeromagnetic data can be used to evaluate potential faults, fractures, and contacts of rocks of contrasting density for their effects on the occurrence of water resources.

\section{Land-Use, Vegetation, and Water-Use Data}

Land-use and vegetation data can be used to evaluate runoff and evapotranspiration components of water budgets used to characterize regional hydrology. Water-use data provide information on ground-water and surface-water withdrawals that also are components in the construction of water budgets. Land-use and vegetation data were obtained from the National Land Cover Characterization Project (U.S. Geological Survey, 2001b) and the Arizona National Biological Information Infrastructure Project (U.S. Geological Survey, 2001c). The land-use and vegetation data are not provided in this report, but are part of the database developed for this study. Water-use data were obtained from municipalities, private water companies, tribal governments, and industrial water users in the study area (table 7).

\section{DATA REQUIREMENTS FOR COMPREHENSIVE INVESTIGATIVE STUDIES}

The hydrogeologic evaluation of water resources and ground-water flow of the Coconino Plateau requires adequate quantitative information that can provide an accurate characterization of surface and subsurface conditions. Although this data report provides substantial information to begin the hydrogeologic evaluation, additional data and monitoring will be needed to fill in data gaps and complete a characterization of the regional hydrogeology. These data needs include the development of a monitoring plan that will provide additional baseline information that can be used to detect future changes in the hydrogeologic system, water use, land use, and vegetation.

Evaluation and analysis of data for the Coconino Plateau is limited by the lack of data for large parts of the study area. In many cases, there are few, if any, well data or other sources of information for the Havasu Basin, for the area between Flagstaff and Williams, and for the area south of Williams into the Verde Valley. Information on springs and vegetation in riparian areas associated with springs is limited to that for a few sites mainly along the south rim of Grand Canyon from Horseshoe Mesa to Boucher Canyon, and along the Verde River and Oak Creek. Current geologic maps of the Coconino Plateau and the greater Grand Canyon region are at scales of $1: 250,000$ or smaller. These maps do not show sufficient detail to develop hydrogeologic framework information needed to infer the occurrence, control, and movement of water from recharge areas to discharge areas on the Coconino Plateau.

Additional data needed to better characterize the hydrogeology of the Coconino Plateau include (1) an inventory of additional wells and springs and verification of existing well and spring information, (2) water-chemistry data that can be used to resolve the origin, occurrence, and movement of water, (3) largescale geologic mapping of surface formations and structure in areas where this information is lacking, (4) selected geophysical information that will enhance understanding of the hydrogeologic framework in areas where direct physical information is lacking, and (5) a program to monitor spring discharge, streamflow, and ground-water levels. As of September 2001, hydrologic data were still being collected and compiled into the database.

Additional well data will provide greater understanding of subsurface hydrogeology for large parts of the Coconino Plateau. Data could be collected from existing wells in those areas where information is currently lacking and from new wells drilled in the study area. Additional spring data will provide a greater understanding of the flow and flow variability in discharge areas of the Coconino Plateau. Areas where this type of information is needed most include the Little Colorado River, the south rim of Grand Canyon from Boucher Creek to Mohawk Creek, all the springs in the Havasu Basin, and springs in tributaries to the Verde River from Paulden downstream to Oak Creek. 
Large-scale geologic mapping of surface formations and structure for the Valle, Cameron, and Williams 1:100,000-scale quadrangles will provide additional details on regional geology and structural trends. This information can be used to better understand the hydrogeologic framework and to construct ground-water flow models that reflect actual conditions.

Geophysical information will provide the means to interpolate surface and subsurface information in areas where physical information from wells, springs, and geologic mapping are lacking. Airborne gravity and aeromagnetic surveys, and resistivity and seismic surveys can provide more detailed information on structural features that are part of the hydrogeologic framework. The southern end of the Havasu Downwarp, the Mesa Butte Fault in the vicinity of Williams, the structurally complex area to the west of Cameron, and converging fault systems south of the south rim of GCNP are all areas in which these data are lacking. All these additional data needs are components of other continuing studies designed to complete the evaluation of the hydrogeology of the Coconino Plateau.

\section{Current and Future Monitoring Activities.-A}

program is in progress to monitor springflow, streamflow, and ground-water levels to provide baseline data and information that could serve as an initial measure for detection of change. Spring monitoring would provide useful information for any further study because of the role that springs play in sustaining riparian areas. Streamflow, spring-discharge, and water-level data increase in value with the length of record, as longer records tend to better document the range of natural variations. The scales of variations mirror those of the climate, ranging from daily to mulitdecadal. Because brief records are limited representations, continued operation of continuousrecords sites would have significant value to ongoing and future studies. Future monitoring could include:

- $\quad$ Monitoring additional springs along the south rim of Grand Canyon on a biannual basis. Springs currently monitored on the south rim of Grand Canyon represent a small portion of the known discharge area to the north (table 2, fig. 6). These springs are being monitored biannually for flow and water chemistry as part of a parallel program with the NPS using standard USGS techniques (Robert Hart, Hydrologist, USGS, Flagstaff,
Arizona, oral commun., 2000). Several of the sites are instrumented for continuous record of stage and flow. Biannual monitoring of springs could be expanded to include additional major discharge points such as Turquoise Canyon, Royal Arch Creek, 140 Mile Canyon, Olo Canyon, and Matkatamiba Canyon. Under the Coconino Plateau RWI, inventory of the remaining regional aquifer springs on the Coconino Plateau has begun and will be completed in 2002.

- Monitoring springs that discharge to the south of the Coconino Plateau. Monitoring these springs would provide additional information on flow variability. Annual and biannual monitoring of selected headwater springs that discharge from the Coconino Plateau to the south and contribute to the base flow of the Verde River Basin has begun as part of the Upper and Middle Verde RWI study (John Hoffmann, Hydrologist, USGS, oral commun., 2001). These data will be incorporated into the Coconino Plateau database as they become available.

- Monitoring streamflow at additional sites. Streams where additional base-flow discharge or runoff data would improve our understanding of the regional hydrogeology include the Little Colorado River below Blue Springs, several topographically closed basins in the Havasu drainage, and Royal Arch Creek. Continuous record streamflowgaging stations may be established and maintained by the USGS at these sites as part of the Coconino Plateau RWI and NPS monitoring programs.

- Monitoring water levels in selected wells on a quarterly basis. Wells in the Flagstaff area, new wells drilled near Williams, and the Havasupai well at Hilltop (fig. 6) are currently being monitored. Water-level data from additional wells in the Valle and Tusayan area would help to fill in data gaps.

\section{SUMMARY}

The Coconino Plateau area contains important surface-water, ground-water, and riparian resources that are under increasing pressure from development. Concerns have been raised about the effects of water development on regional springs, surface-water and riparian resources, and the availability and 
sustainability of regional-water supplies. Stakeholders agree that an improved understanding of the regional hydrogeologic system is needed to address the concerns of water supply and ground-water sustainability. Such an understanding requires a base of information that adequately describes the system. That base of information currently does not exist for the Coconino Plateau.

In cooperation with the City of Williams, the USGS compiled available water-resources data for the Coconino Plateau from October 2000 through September 2001 as the initial phase of a study of the regional hydrogeology. The USGS compiled data on climate, geology, ground water, surface water, water chemistry, land use, vegetation, and water use. The study area for this report encompasses about 10,300 square miles in northern Arizona including all of the Coconino Plateau (about 5,000 square miles) and parts of the Little Colorado River and Verde River Basins. These data will serve as the core of information used to guide additional data collection, monitoring, evaluation, and interpretation as part of ongoing studies.

Most of the climate data available for the study area are from the National Weather Service. There are 36 reporting stations within the study area and 17 of those are currently active. The average annual precipitation ranges from 5.5 to $27.7 \mathrm{in}$. for periods of record that range from 3 to 89 years. Additional precipitation data were obtained from a statisticalgeographical approach model developed at Oregon State University called PRISM. PRISM uses digital elevation model data to determine variations in precipitation as a function of elevation. The general geology and geologic structure of the region is known or inferred from more detailed geologic investigations in adjacent areas. Geologic mapping studies are currently ongoing to improve our understanding of areal geology and geologic structure in the detail needed for ongoing water-resources studies.

The database assembled for this study has information on 1,767 wells and 295 springs. Well information includes location, total depth, depth to water, well design, and a list of available borehole logs and additional information. Well-logs and pump or aquifer-test data also are available for some wells. Well depths range from a few feet to $6,500 \mathrm{ft}$ below land surface. Well yields range from less than 1.0 to $1,293 \mathrm{gpm}$. Of the 295 springs mapped in the study area, 164 have been inventoried with reliable information on the location, geologic unit, flow rate, and water chemistry. Spring flows range from less than 1 to more than 48,000 gpm.

Streamflow data are available for 66 streamflow sites within the study area. Of these, 29 are continuous record sites for flow, and of these, 13 were still active in the 2001 water year. Peak-flow, partial-record information was obtained for 32 sites within the study area; 4 of these sites are active.

The water-chemistry data include information for 22 streams, 156 springs, and 420 wells. Of 1,364 water samples analyzed, 1,090 were analyzed only for major cations and anions; 610 were analyzed for nutrients. Trace-element chemistry is available for 365 samples, and radionuclides or isotope data are available for 120 of the samples. Water chemistry is varied throughout the study area. Specific conductance values range from 8.0 to $20,200 \mu \mathrm{S} / \mathrm{cm}$ and dissolved solids range from 31 to 12,400 to $\mathrm{mg} / \mathrm{L}$. Alkalinity ranges from 26 to $483 \mathrm{mg} / \mathrm{L}$, and $\mathrm{pH}$ ranges from 5.8 to 10.8 . In 264 of the samples, some major ions, nutrients, trace elements, and radionuclides exceeded the USEPA MCLs or SMCLs for drinking water.

Land-use and vegetation data were obtained from the National Land Cover Characterization Project and the Arizona National Biological Information Infrastructure project. The land-use and vegetation data are not provided in this report, but are part of the database developed during this study. Water-use data were obtained from municipalities, private water companies, tribal governments, and industrial water users in the study area.

The hydrogeologic evaluation of water resources and ground-water flow of the Coconino Plateau requires adequate quantitative information that can provide an accurate characterization of surface and subsurface conditions. While this data report provides substantial information to begin the hydrogeologic evaluation, additional data and monitoring could fill in data gaps and be used to better characterize the regional hydrogeology. The additional data could include: (1) an inventory of additional wells and springs and verification of existing well and spring information, (2) water-chemistry data that can be used to resolve the origin, occurrence, and movement of water, (3) largescale geologic mapping of surface formations and structure in areas where the information is lacking, (4) selected geophysical information that will enhance understanding of the hydrogeologic framework in areas 
where direct physical information is lacking, and (5) a program to monitor spring discharge, streamflow, and ground-water levels at additional sites. As of September 2001, hydrogeologic data were still being collected and compiled into the database.

\section{REFERENCES CITED}

Anning, D.W., and Duet, N.R., 1994, Summary of groundwater conditions in Arizona, 1987-90: U.S. Geological Survey Open-File Report 94-476, 2 plates.

Arizona Department of Water Resources, 2001, Arizona Land Resource Information System GIS data: accessed March 2001, at URL http://www.land.stat.az/ alris/index.html/

Arizona State Land Department, 1998, State of Arizona surface management responsibility: Arizona State Land Department map, second preliminary edition, May 12, 1998, scale 1:700,000.

Beus, S.S., and Morales, Michael, 1990, Grand Canyon Geology: Oxford University Press and Museum of Northern Arizona Press, New York and Flagstaff, Arizona, $518 \mathrm{p}$.

Billingsley, G.H. and Hendricks, J.D., 1989, Physiographic features of Northwestern Arizona, in Elston, D.P., Billingsley, G.H., and Young, R.A., eds., Geology of Grand Canyon, Northern Arizona (with a Colorado River guide): American Geophysical union, Washington, D.C., Chapter 4, p. 67-71.

Billingsley, G.H., Spamer, E.E., and Menkes, Dave, 1997, Quest for the pillar of gold, the mines and miners of Grand Canyon: Grand Canyon Association monograph no. 10, Grand Canyon, Arizona, 112 p.

Billingsley, G.H., Wenrich, K.J., and Huntoon, P.W., 2000, Breccia-Pipe and geologic map of the southeastern part of the Hualapai Indian Reservation and Vicinity, Arizona: U.S. Geological Survey Geologic Investigations Series I-2643, 18 p., 2 sheets, scale $1: 48,000$.

Bills, D.J., Truini, Margot, Flynn, M.E., Pierce, H.A., Catchings, R.D., and Rymer, M.J., 2000, Hydrogeology of the regional aquifer near Flagstaff, Arizona, 199497: U.S. Geological Survey Water-Resources Investigation Report 00-4122, 143 p., 4 plates.

Blakey, R.C., 1990, Stratigraph and geologic history of Pennsylvanian and Permian rocks, Mogollon Rim region, central Arizona and vicinity: Geological Society of America Bulletin, v. 102, no. 9. p. 1189-1217.

Chavez, P.S., Jr., Velasco, Miguel, and Sides, S.C., 1996, Ground-water resources evaluation, Flagstaff, Arizona-Remote-sensing component: U.S. Geological Survey Open-File Report 96-739, 27 p.
Cooley, M.E., Harshbarger, J.W., Akers, J.P., and Hardt, W.F., 1969, Regional hydrogeology of the Navajo and Hopi Indian Reservations, Arizona, New Mexico, and Utah, with a section on Vegetation by O.N. Hicks: U.S. Geological Survey Professional Paper 521-A, 61 p., 9 plates.

Cooley, M.E., 1976, Spring flow from pre-Pennsylvanian rocks of the southwestern part of the Navajo Indian Reservation, Arizona: U.S. Geological Survey Professional Paper 521-A, 13 p., 2 plates.

Daly, Christopher, Neilson, R.P., and Phillips, D.L., 1994, A statistical-topographic model for mapping climatological precipitation over mountainous terrain: Journal of Applied Meteorology, v. 33, p. 140-158.

Errol L. Montgomery and Associates, 1999, Supplemental assessment of hydrogeologic conditions and potential effects of proposed groundwater withdrawal, Coconino Plateau Groundwater Sub-Basin, Coconino County, Arizona June 1999: Appendix of the Final

Environmental Impact Statement for Tusayan Growth, Kaibab National Forest, Williams, Arizona, July 1999, $256 \mathrm{p}$.

Fellows, L.D., 2000, Earthquake hazards in Arizona: Arizona Geology, v. 30 no. 1, Spring 2000, Arizona Geological Survey, Tucson, p. 104.

Fitzgerald, J., 1996, Residence time of ground water issuing from the South Rim aquifer in the Eastern Grand Canyon: Las Vegas Nevada, Department of Geoscience, University of Nevada, Las Vegas, master's thesis, 103 p.

Ghioto, Gary, 2001, Hitting the Wall: Arizona Daily Sun, February 21, 2001, Flagstaff, Arizona, v. 55, no. 127, p. 1.

Goings, D.B., 1985, Spring flow in a portion of Grand Canyon National Park, Arizona: Las Vegas Nevada, Department of Biological Sciences, Cooperative National Park Resources Studies Unit, University of Nevada, Las Vegas, master's thesis, CPSU/UNLV 033/01, $60 \mathrm{p}$.

Harshbarger and Associates and John Carollo Engineers, 1972, Water resources report, City of Flagstaff, Arizona; Harshbarger and Associates and John Carollo Engineers duplicate report, Tucson, Arizona, $124 \mathrm{p}$.

Hart, R.J., Ward, J.J., Bills, D.J., and Flynn, M.E., 2002, Generalized hydrogeology and ground-water budget for the $\mathrm{C}$ aquifer, Little Colorado River Basin and parts of the Verde and Salt river basins, Arizona and New Mexico: U.S. Geological Survey Water-Resources Investigations Report 02-4026, 47 p., 1 sheet.

Huntoon, P.W., Billingsley, G.H., and Clark, M.D., 1981, Geologic map of the Hurricane fault zone and vicinity, western Grand Canyon, Arizona: Grand Canyon Natural History Association, Grand Canyon, Arizona, scale, 1:48,000. 
Huntoon, P.W., Billingsley, G.H., and Clark, M.D., 1982, Geologic map of the lower Granite Gorge and vicinity, western Grand Canyon, Arizona: Grand Canyon Natural History Association, Grand Canyon, Arizona, scale 1:48,000.

Huntoon, P.W., Billingsley, G.H., Breed, W.J., Sears, J.W., Ford, T.D., Clark, M.D., Babcock, R.S., and Brown, E.H.,1986, Geologic map of the eastern part of the Grand Canyon National Park, Arizona: Grand Canyon Natural History Association, Grand Canyon, Arizona, scale $1: 62,500$.

Kaibab National Forest, 1999, Final environmental impact statement for Tusayan growth, Coconino County, Arizona: U.S. Department of Agriculture, Forest Service, Kaibab National Forest, Williams, Arizona, August, 1999, 399 p., 1 appendix.

Kasindorf, Martin, and McMahon, Patrick, 2001, Arizona's hispanic population grew by 88 percent: USA Today, accessed April 24, 2001, at URL

http://www.usatoday.com/news/census/az.htm/Krantz, R.W., 1989, Laramide structures of Arizona, in Jenney, J.P. and Reynolds, S.J., eds., 1989, Geologic evolution of Arizona: Tucson, Arizona, Arizona Geological Society Digest 17, p. 463-483.

Krantz, R.W., 1989, Laramide structures of Arizona, in Jenney, J.P., and Reynolds, S.J., eds., Geologic evolution of Arizona: Tucson, Arizona Geological Society Digest 17, p. 463-483.

Marx, D.E., 1995, Deposition of travertine along Havasu Creek, Arizona: Environmental Engineering Chemistry Lab, 21 p.

McGavock, E.H., Anderson, T.W., Moosburner, Otto, and Mann, L.J., 1986, Water resources of Southern Coconino County, Arizona: Arizona Department of Water Resources Bulletin 4, 53 p., 2 plates.

Metzger, D.G., 1961, Geology in relation to the availability of water along the south rim, Grand Canyon National Park, Arizona: U.S. Geological Survey Water-Supply Paper 1475-C, 135 p., 1 plate.

Montgomery J.M., 1981, Lake Mary and Woody Mountain well locations and designs (LM-8, WM-8, WM-T), City of Flagstaff, Arizona: James M. Montgomery Consulting Engineers, Inc., Phoenix, Arizona, 11 p.

National Oceanographic and Atmospheric Administration, 1999, Climatological data, annual Summary, Arizona: National Oceanographic and Atmospheric Administration, National Data Center, Ashville, North Carolina, ISSN 1045-0387, v. 103, no. 13, 27 p.

National Park Service, Grand Canyon National Park, 2001, Quick look: accessed April 2001, at URL http://www.nps.gov/grca/grandcanyon/quicklook.htm/
Natural Resources Consulting Engineers, Inc., 1999, Field study of springs and other hydrologic features on the Havasupai Reservation, Arizona: Natural Resources Engineers, Inc., Fort Collins, Colorado, 28 p.

Natural Resources Consulting Engineers, Inc., 2000, Field study of springs and Bar Four Well on the Havasupai Reservation, Arizona: Natural Resources Engineers, Inc., Fort Collins, Colorado, 26 p.

Nealey, D.L. and Sheridan, M.F., 1989, Post-Larimide volcanic rocks of Arizona and northern Sonora, Mexico, and their inclusions, in Jenney, J.P., and Reynolds, S.J., eds., Geologic evolution of Arizona: Tucson, Arizona, Arizona Geological Society Digest 17, p. 609-647.

Newhall, C.G., Ulrich, G.E., and Wolfe, E.W., 1987, Geologic map of the southwest part of the San Francisco volcanic field, north-central Arizona: U.S. Geological Survey Miscellaneous Field Studies Map MF-1958, scale, 1:50,000.

Parker, J.T.C and Flynn, M.E., 2000, Investigation of the geology and hydrology of the Mogollon Highlands of Central Arizona: A project of the Arizona Rural Watershed Initiative: U.S. Geological Survey Fact Sheet 159-00, 4 p.

Paulson, R.W., Chase, E.B., Williams, J.S., and Moody, D.W., 1993, National Water Summary 1990-91, hydrologic events and stream water quality: U.S. Geological Survey Water-Supply Paper 2400, 590 p.

Peirce, H.W., 1984, The Mogollon Escarpment: Tucson, Arizona Bureau of Geology and Mineral Technology, fieldnotes, v. 14, no. 21, p. 8-11.

Phillips, J.D., Duval, J.S., and Ambroziak, R.A., 1993, National geophysical data grids: gamma-ray, gravity, magnetic, and topographic data for the conterminous United States: U.S. Geological Survey Digital Data Series DDS-9, 1 CD-ROM.

Reynolds, S.J., 1988, Geologic Map of Arizona: Tucson, Arizona Geological Survey Map M-26, scale, $1: 1,000,000$.

Sellers, W.D., Hill, R.H., and Sanderson-Rae, M., eds., 1985, Arizona climate-One hundred years, 1885-1985:

Tucson, University of Arizona Press, 143 p.

Shoemaker, E.M., Squires, R.L., and Abrams, M.J., 1978, Bright Angel and Mesa Butte Fault systems of northern Arizona, in Smith, R.B., and Eaton, G.P., eds., Cenozoic tectonics and regional geophysics of the western Cordillera: Geological Society of America Memoir 152, p. 341-367.

Sorauf, J.E., and Billingsley, G.H., 1991, Members of the Toroweap and Kaibab Formations, Lower Permian, northern Arizona, and southwestern Utah: Rocky Mountain Association of Geologists, The Mountain Geologist, v. 28, no. 1, p. 9-24. 
Twenter, F.R. and Metzger, D.G., 1963, Geology and ground water in Verde Valley - the Mogollon Rim region, Arizona: U.S. Geological Survey Bulletin 1177, 132 p., 1 plate.

Ulrich, G.E., Billingsley, G.H., Hereford, Richard, Wolfe, E.W., Nealey, L.D., and Sutton, R.L, 1984, Map showing geology, structure, and uranium deposits of the Flagstaff $1^{\circ} \times 2^{\circ}$ quadrangle, Arizona: U.S. Geological Survey Miscellaneous Investigations Series Map I1446 , scale $1: 250,000$.

U.S. Census Bureau, 2001, Census 2000 data for the state of Arizona: accessed April 24, 2001, at URL http://www.census.gov/census2000/states/az.html/

U.S. Environmental Protection Agency, 2002, U.S. Environmental Protection Agency National Primary Drinking Water Standards, EPA, 816-01-007, accessed January 23, 2002, at URL http:/www.epa.gov/safewater/mcl.html/

U.S. Geological Survey, 2001a, U.S. Geological National Elevation Dataset: accessed June 6, 2001, at URL http://edents12.cr.usgs.gov/ned/

U.S. Geological Survey, 2001b, U.S. Geological Survey National Land Cover Characterization Project: accessed September, 2001, at URL http://.landcover.usgs.gov/nationallandcover.html/

U.S. Geological Survey, 2001c, U.S. Geological Survey Arizona National Biological Information Infrastructure Project: accessed July 30, 2001, at URL http://usgs.brd.srnr.arizona.edu/nbii/index.html/

U.S. Geological Survey, 2000d, U.S. Geological Survey Earth Resources Observation Satellite data center, accessed December 2000, at URL http://edcwww.cr.usgs.gov/
Wenrich, K.J., Billingsley, G.H., and Huntoon, P.W., 1997, Breccia-Pipe and geologic map of the northeastern part of the Hualapai Indian Reservation and vicinity, Arizona: U.S. Geological Survey Miscellaneous Investigations Series I-2440, 19 p., 2 sheets, scale 1:48,000.

Wenrich, K.J., Boundy, S.Q., Aumente-Modreski, Regina, Schwarz, S.P., Sutphin, H.B., and Been, J.M., 1994, A hydrogeochemical survey for mineralized breccia pipes - Data from springs, wells, and streams on the Hualapai Indian Reservation, northwestern Arizona: U.S. Geological Survey Open-File Report 93-619, $66 \mathrm{p}$.

Wilson, Eric, 2000, Geologic framework and numerical flow models of the Coconino Plateau aquifer, Grand Canyon, Arizona: Flagstaff, Arizona, Department of Geology, Northern Arizona University, master's thesis, 72 p.

Wolfe, E.W., Ulrich, G.E., Holm, R.F., Moore, R.B., and Newhall, C.G., 1987, Geologic map of the central part of the San Francisco volcanic field, north-central Arizona: U.S. Geological Survey Miscellaneous Field Studies Map MF-1959, scale 1:50,000.

Woodhouse, Elizabeth, Flynn, M.E., Callegary, James, and Jannusch, J., 2001, Investigation of geology and hydrology of the Upper and Middle Verde River Watershed of Central Arizona: A project of the Rural Watershed Initiative: U.S. Geological Survey Fact Sheet 059-02, 4 p.

Woods and Poole Economics, Incorporated, 1999, 1999 Arizona State Profile report: Washington, D.C., January $1999,220 \mathrm{p}$.

Zukosky, K.A., 1995, An assessment of the potential to use water chemistry parameters to define ground water flow pathways at Grand Canyon National Park, Arizona: Las Vegas, Nevada, Department of Geoscience, University of Nevada Las Vegas, master's thesis, 105 p. 



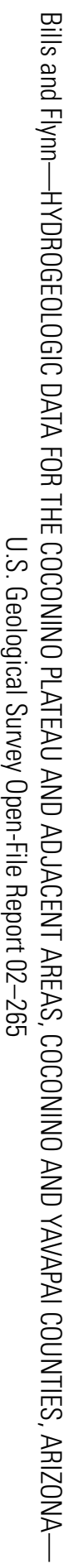

(4) Printed on recycled paper 